\title{
RAZONES JURÍDICAS QUE JUSTIFICAN LA IMPROCEDENCIA DE APLICAR EL ESTATUTO DE LA NULIDAD DE DERECHO PÚBLICO CONTRA LOS ACTOS JURISDICCIONALES
}

\author{
LEGAL ARGUMENTS FOR THE INADMISSIBILITY OF APPLYING THE \\ NULLITY STATUTE UNDER PUBLIC LAW AGAINST JUDICIAL ACTS
}

\author{
Jaime Carrasco Poblete ${ }^{1}$
}

\begin{abstract}
RESUMEN: La presente investigación constituye una respuesta desde el ámbito del Derecho Procesal a aquella parte de la doctrina que afirma la aplicación de la nulidad de derecho público a los actos jurisdiccionales. Lo que se pretende es exponer diversas razones que permitan demostrar que el estatuto de la nulidad de derecho público es jurídicamente improcedente aplicarlo contra los actos jurisdiccionales que adolecen de defectos o vicios de naturaleza procesal.
\end{abstract}

Palabras clave: Nulidad de derecho público, nulidad de pleno derecho, nulidad procesal, vicios procesales, invalidez de los actos procesales.

ABSTRACT: This work is a response from the field of procedural law to part of the doctrine that supports the application of the public law nullity to judicial acts. The purpose of this research is to present a variety of reasons which show that the status of the invalidity of public law is legally inadmissible against judicial acts tainted by defects or vices of a procedural nature.

Key words: Public law nullity, procedural nullity, procedural defects, invalidity of procedural acts.

\section{INTRODUCCIÓN}

En la actualidad existe una tendencia doctrinal que reabre el debate en cuanto a la aplicación de la nulidad de derecho público a los actos jurisdiccionales. Sin perjuicio de aquellos que abogan que la nulidad de derecho público es aplicable a los actos jurisdiccionales, actualmente, derivada de esta teoría, aparece la tesis postulada por Otero Lathrop, denominada por él como nulidad procesal de derecho público, quien afirma que esta tiene un estatuto propio y diverso de la nulidad procesal $^{2}$.

\footnotetext{
${ }^{1}$ Abogado, Licenciado en Ciencias Jurídicas (Universidad de los Andes), Doctor en Derecho (Universidad de los Andes), Máster en Derecho de la Empresa (Universidad de los Andes), Máster en Derecho Público (Universidad de los Andes), Profesor de Derecho Procesal y Coordinador del Departamento de Derecho Procesal de la Facultad de Derecho de la Universidad Andrés Bello, Santiago, Chile. Dirección Postal: Bellavista 0121, tercer piso, Providencia, Santiago, Chile. Correos electrónicos: jaime.carrasco@unab.cl; jcarrasco@ortfesa.cl

2 Otero (2009) pp. 253-281.
} 
Como se sabe, con mayor o menor amplitud, la doctrina discute la aplicación de la nulidad de derecho público a los actos legislativos y a los jurisdiccionales. De un modo concreto, algunos autores son partidarios de aplicar esta sanción a todos los actos de la administración o de un órgano público sin distinción alguna, concediendo a la nulidad de derecho público un carácter universal o absoluto ${ }^{3}$. Otros, en cambio, abogan que es improcedente aplicar esta sanción tanto a los actos legislativos como a los jurisdiccionales, asumiendo una tesis relativa en cuanto a la aplicación de esta nulidad ${ }^{4}$. Por otro lado, algunas opiniones doctrinales afirman que es inapropiado aplicar la nulidad de derecho público a los actos jurisdiccionales, restringiendo su aplicación solo a los actos administrativos y a los legislativos 5 .

3 En este sentido cfr. Soto (2009) p. 439, quien al analizar el art. 7 inc. $3^{\circ}$ de las CPR, en relación al adjetivo todo y al sustantivo acto dispone que: "cuando se dice de algo 'todo', se está significando en ello que es 'sin excepción', que nada se excluye de su afirmación, que nada queda fuera de su alcance, que lo comprende en su enteridad. Cuando se prescribe en el inicio del inciso $3^{\circ}$ del artículo $7^{\circ}$ de la Constitución que 'todo acto', lo que está ordenando y estableciendo es que ningún acto queda exceptuado de su mandato, sea cual fuere tal acto, ya en la función en que recae, ya en la jerarquía de su autor, ya en su naturaleza específica. En efecto. Ello rige y es aplicable a todo tipo de función estatal, desde la constituyente pasando por la legislativa y la jurisdiccional hasta la administrativa y contralora: cualquier acto, de cualquiera de dichas funciones, que contravenga el artículo $7^{\circ}$ es nulo; ninguno queda excluido, pues, todos están sometidos en su gestación (procedimiento de elaboración) como en su contenido a la Constitución, sin excepción. De allí que sea inconstitucional pretender que este precepto (artículo $7^{\circ}$ inciso $3^{\circ}$ en relación con sus incisos $1^{\circ}$ y $2^{\circ}$ precedentes) no fuera aplicable a algún acto de alguna autoridad estatal y pudiera, en consecuencia, escapar a su imperatividad y operatividad directa (artículo $6^{\circ}$ inciso $2^{\circ}$ ). Bajo esta disposición está tanto el acto constituyente que lo viola, como cualquier acto legislativo o de órgano parlamentario (lato sensu). Jurisdiccional, administrativo y contralor que lo contraviene". En este mismo sentido cfr. Bocksang (2013) p. 49-75; Fiamma (1991) pp. 91-98; PfefFer (2005) p. 138. Introduciendo un nuevo concepto de nulidad procesal de derecho público al ámbito jurisdiccional se manifiesta ОTERO (2009) pp. 267 y ss., quien explica que ella es procedente, además, por las siguientes causales: “... la inobservancia de las normas de procedimiento establecidas por la ley para el conocimiento y resolución del conflicto de relevancia procesal sometido a la jurisdicción" y "la violación a las normas del debido proceso".

${ }^{4}$ En este sentido JaRA (2004) pp. 85-93, quien afirma que "tratándose de actos jurisdiccionales, si bien estos pueden ser pasibles de la sanción anulatoria, ella adopta rasgos y atributos propios que la distinguen como un instituto especial en que se hallan particularmente acentuados los principios de conservación, trascendencia y sanabilidad así como la consagración de un reglamentado régimen de convalidación por transcurso del tiempo mediante reducidos plazos de caducidad que instan la confirmación del acto procesal irregular". En este mismo sentido BERNASCHINA (1950) pp. 408-410, quien solo la hace aplicable a los actos administrativos excluyendo los legislativos y jurisdiccionales. Respecto de los actos jurisdiccionales BeRNASCHINA sostiene que: "a pesar que los Tribunales de Justicia crean actos estatales y de que sus resoluciones son imputables al Estado mismo, por órganos de este, no cabe aplicar las reglas de las nulidades de derecho público a las decisiones de los tribunales, porque se opondrían al imperio y a la independencia total de que se ha querido revestir a la judicatura por las normas positivas. En efecto, existen reglas especiales que han dado origen a una nulidad especial, la llamada nulidad procesal que impide aplicar las reglas que hemos deducido de los artículos 4, 23 y 75 de la Constitución Política de 1925". Esta misma opinión cfr. Bernaschina (1958) t. I, pp. 253 y ss. En sentido similar cfr. Huneeus (1890) pp. 383 y ss.; JARA (1950) p. 38. Una posición intermedia la sostiene ReYEs (2000) pp. 32-38, al exponer que no siempre se aplica la nulidad de derecho público a los actos legislativos y a los jurisdiccionales pues, existen mecanismos de control previos lo cuales deben armonizarse con las normas de la nulidad de derecho público.

${ }^{5}$ En este sentido Martínez (2003) pp. 14-15, quien limita la aplicación de la nulidad de derecho público solo a los actos administrativos y a los legislativos. Así, respecto de los segundos, al explicar la nulidad de derecho público de la ley, sostiene que: "al analizar esta característica pareciera pasarse por alto que la Nulidad de Derecho Público no solo puede afectar a actos administrativos, sino que también legislativos". Respecto a los actos jurisdiccionales el autor se opone a que se aplique este régimen anulatorio. 
Los argumentos de la teoría clásica que afirma la procedencia de la nulidad de derecho público a todos los actos de los órganos del Estado, en síntesis, se basa en una interpretación exegética del inciso $3^{\circ}$ del artículo 7 de la CPR y aducen razones de carácter histórico. Para los partidarios de esta tesis, la nulidad de derecho público se caracteriza por ser una nulidad de pleno derecho (ipso iure), de carácter insanable, no susceptible de subsanación ni convalidación, atribuyéndole un carácter imprescriptible ${ }^{6} \mathrm{y}$, concluyen, afirmando que en cuanto a sus efectos se trata de una inexistencia del respectivo acto ${ }^{7}$.

Por otro lado, Otero LATHRop promueve la aplicación de la nulidad de derecho público a los actos jurisdiccionales, denominándola nulidad procesal de derecho público ${ }^{8}$. El referido autor afirma que: "en materia procesal (...) hay dos causales adicionales que producen la nulidad procesal de derecho público, sea respecto del proceso o del juicio. La primera, es la inobservancia de las normas de procedimiento establecidas por la ley para el conocimiento y resolución del conflicto de relevancia procesal sometido a la jurisdicción. La segunda es la violación a las normas del debido proceso"9.

El fundamento para sostener lo anterior radica, en síntesis, que en cualquier materia del Derecho, el órgano que debe conocer del conflicto debe hacerlo de acuerdo con las normas de procedimiento que la ley dispone, estando vedado a las partes y al juez modificar tales preceptos, a menos que la ley otorgue expresamente esa facultad. De existir tal modificación por las partes o por el juez, entonces, el o los actos procesales desarrollados durante el procedimiento adolecen de nulidad procesal de derecho público, la que el tribunal debe declarar de oficio, sin que exista forma alguna de saneamiento y aun cuando no exista perjuicio alguno para las partes ${ }^{10}$ porque se trata de una vulneración a normas de orden público, transgrediéndose el artículo 7 de la Carta Fundamental (en la forma que prescriba la ley) ${ }^{11}$.

Respecto a la inobservancia del debido proceso como causal de la nulidad procesal de derecho público, se argumenta que el contenido de este, establecido en el artículo $19 \mathrm{~N}^{\circ}$ 3 de la CPR y las garantías y derechos reconocidos por tratados internacionales ratificados

6 Una opinión crítica a la imprescriptibilidad de la acción de nulidad de derecho público cfr. POBLETE (2013) pp. 335-359. Sobre la prescripción de la acción y una serie de deficiencias o insuficiencias dogmáticas de la nulidad de derecho público véase el trabajo de Concha (2013) pp. 107-112.

7 Estas conclusiones son una síntesis de las explicaciones que indican autores como, entre otros, SoTO (2009) pp. 443-483; BOCKSANG (2006) pp. 91-116; Fiamma (1986) pp. 123-128.

8 Otero (2009) pp. 267 y ss.

9 Otero (2009) pp. 267-269.

10 La jurisprudencia se ha manifestado en contra de esta opinión. En efecto, la CA. de Santiago, 22 de diciembre de 2008, Rol N 9556-2004 (Cita LegalPublishing: CL/JUR/6153/2008; 41529), dispuso que: “... Empero, puede decirse, a modo de introducción que, como toda nulidad, constituye una sanción, siendo requisito indispensable que el acto que se pretende nulo haya originado o causado un daño o perjuicio. Cabe recordar que constituye un axioma jurídico el que no hay nulidad sin perjuicio, lo cual ocurre con todas las variedades bajo las que se presenta esta institución en el derecho chileno. Por ejemplo, la casación, en sus dos formas, que expresamente exigen agravio, así como la nulidad incidental prevista tanto en el Código de Procedimiento Civil como en el antiguo Código de Procedimiento Penal. Igualmente, el recurso de nulidad del nuevo procedimiento en lo penal, previsto en el Código Procesal Penal requiere la presencia de agravio o perjuicio. Por lo tanto, la nulidad de derecho público no puede escapar de este principio, lo cual es de toda lógica, porque si el acto administrativo es inocuo, carece de todo sentido declararlo nulo de derecho público". (considerando $8^{\circ}$, párrafo $2^{\circ}$ ), (El destacado es nuestro).

11 OTERo (2009) p. 268. 
por Chile y que se encuentren vigentes, son de orden público y su infracción origina la nulidad procesal de derecho público ${ }^{12}$.

Para explicar el funcionamiento de esta especie de nulidad -según enseña Otero Lathrop- hay que distinguir si se impetra antes de existir sentencia ejecutoriada o si se deduce con posterioridad a ello. En el primer caso, se forma un incidente de nulidad que puede interponerse en cualquier estado del juicio y hasta antes de la vista de la causa. En caso contrario, se trata de una acción que genera un nuevo proceso jurisdiccional que debe interponerse ante el tribunal competente y que se tramitará conforme a las reglas del juicio ordinario o del sumario, si es procedente ${ }^{13}$.

Tal como se explicará, disentimos de aquellas tesis que afirman que la nulidad de derecho público y, la más específica, nulidad procesal de derecho público sean aplicables a los actos jurisdiccionales que adolecen de alguna irregularidad.

Para demostrar nuestra hipótesis, consideraremos los inconvenientes de aplicar la nulidad procesal de derecho público a los actos jurisdiccionales los cuales se pueden sintetizar de la siguiente forma: i) se quebranta el ámbito de aplicación de la nulidad procesal de derecho público; ii) no se distingue que la actividad jurisdiccional sea de auctoritas y no de potestas; iii) se infringe el principio de legalidad; iv) se atenta contra la historia fidedigna del establecimiento del Código de Procedimiento Civil; v) se vulnera el fin y razón de ser de la cosa juzgada; vi) se transgreden los límites del sistema anulatorio que impiden declarar la nulidad; vii) la nulidad de derecho público, en el evento que fuese aplicable a los actos jurisdiccionales no podría operar ipso iure; viii) nulidad de derecho público desconoce flagrantemente el principio de trascendencia del perjuicio que exige la nulidad procesal; y ix) la aplicación de la nulidad procesal de derecho público a los actos jurisdiccionales sobrepasa el régimen de impugnación de la actividad procesal irregular regulado en el Código de Procedimiento Civil. A continuación aludiremos a los problemas precedentes.

\section{2. ÁMBITO DE APLICACIÓN DE LA NULIDAD PROCESAL DE DERECHO PÚBLICO}

La primera crítica que hacemos se refiere al ámbito de aplicación de la nulidad de derecho público.

Una parte de la doctrina constitucional y administrativa asevera que la nulidad de derecho público se trata de una sanción de ineficacia que corresponde aplicar a los actos de todos los órganos del Estado desarrollados con infracción al principio de juridicidad, incluyendo, tanto los actos administrativos, legislativos como jurisdiccionales, y respecto de estos últimos, a todas las resoluciones judiciales, a todos los actos del juez cuando estos infrinjan, ya sea las normas de procedimiento establecidas por la ley para el conocimiento y resolución del conflicto de relevancia procesal sometido a la jurisdicción, ya sea las normas del debido proceso.

\footnotetext{
12 Otero (2009) p. 269.

13 Cfr. Otero (2009) p. 271.
} 
Consideramos que la precedente interpretación es extensa, producto del análisis exegético que se suele hacer respecto del inciso $3^{\circ}$ del artículo 7 de la Constitución.

En efecto, en cuanto al ámbito de aplicación de esta nulidad, según explica Soto Kloss, el artículo 7 inciso $3^{\circ}$ se refiere a todo acto, razón por la cual, "cuando se dice de algo 'todo', se está significando en ello que es 'sin excepción', que nada se excluye de su afirmación, que nada queda fuera de su alcance, que lo comprende en su enteridad. Cuando se prescribe en el inicio del inciso $3^{\circ}$ del artículo $7^{\circ}$ de la Constitución que 'todo acto', lo que está ordenando y estableciendo es que ningún acto queda exceptuado de su mandato, sea cual fuere tal acto, ya en la función en que recae, ya en la jerarquía de su autor, ya en su naturaleza específica" ${ }^{\prime 4}$.

En nuestra opinión, el campo de acción de la nulidad de derecho público son los actos que provienen de la administración, cuando esta ejerce sus potestades fuera de los límites que la Constitución o la ley les asignan. Según el texto de la misma, la nulidad de derecho público se aplicará cuando un órgano del Estado actúa sin previa investidura regular, excede su competencia o no actúa en la forma que señala la ley.

En lo que se refiere a los actos que competen al Poder Judicial, la nulidad de derecho público puede afectar a ciertos actos que tienen relación con el mismo, como puede ser la organización de los tribunales y las atribuciones de los jueces que lo componen como, por ejemplo, la creación de un tribunal sin mandato legal; o el nombramiento inválido de un juez; o que un funcionario administrativo se atribuya potestad jurisdiccional sin que exista una investidura regular; pero en ningún caso se refiere a los actos procesales (actuaciones judiciales y resoluciones judiciales en general) que se desarrollan durante un proceso jurisdiccional.

La amplia interpretación exegética que se hace del adjetivo "todo" referido al sustantivo "acto" que dispone el artículo 7 CPR debe ser morigerada y no abarcar lo que el Constituyente, a nuestro comprender, no ha querido englobar. En efecto, lo que el Constituyente ha pretendido es que la administración actúe dentro de la legalidad vigente, sin que ejerza potestades no atribuidas por el ordenamiento jurídico, pues, el Derecho controla a los poderes del Estado.

Esta interpretación que abarca la universalidad de los actos que emanan de los órganos del Estado (actos administrativos, legislativos y jurisdiccionales) presenta una serie de inconvenientes o inconsistencias que sugieren matizar aquel proceso hermenéutico y restringir la aplicación de la nulidad de derecho público, excluyendo su aplicación a los actos jurisdiccionales.

En primer lugar, hay que tener presente que la Constitución tiene un componente político y otro jurídico. En palabras de Pereira Menaut, "toda constitución tiene siempre, por el mero hecho de serlo, una componente política, tan evidente que no merece la pena ser discutida. (...) Todas las constituciones dignas de tal nombre deben aceptar ciertos objetivos netamente políticos, como el freno al poder y el aseguramiento de los derechos y libertades, o la sujeción del gobierno al Derecho, y todas han de pronunciarse acerca de cuestiones típicamente políticas, como la forma de estado y la de gobierno. (...) El elemento

14 Soto (2009) p. 439. En el mismo sentido cfr. BocKSANG (2006) pp. 98 y ss. 
jurídico está también presente, constitutivamente y no per accidens, en la limitación del poder por medio del Derecho y en la atribución de libertades y derechos a los ciudadanos"15.

Son las atribuciones de cada autoridad pública otorgadas por la Constitución o la ley las que se tratan de delimitar y a la vez separar unas de otras. La Constitución, en este contexto, crea órganos y también les asigna o atribuye determinadas competencias. En efecto, tanto el Poder Ejecutivo, el Legislativo como el Judicial tienen atribuciones asignadas por la Constitución y desarrolladas por la ley, pues, cada uno de ellos cumple una función determinada que, en el caso del Poder Judicial es conocer, juzgar y hacer ejecutar lo juzgado a través del proceso legalmente tramitado, siendo este un instrumento para el ejercicio de la función jurisdiccional.

Así, es evidente que si el Poder Judicial se reúne en pleno y dicta un nuevo Código de Procedimiento Civil, dicho actuar está fuera de su competencia y dicho Código no se dictó de acuerdo a la forma que prescribe la ley, porque la función del Poder Judicial es, en general, conocer, juzgar y hacer ejecutar lo juzgado y no acometer labores legislativas que están entregadas al órgano legislador. Lo mismo si el Congreso se atribuye otras potestades que fueron entregadas al Ejecutivo y viceversa.

La creación de órganos y atribución de competencias o funciones que asignan tanto la Constitución como la ley, pretenden que cada poder del Estado actúe dentro de su ámbito, sin extralimitar sus poderes. Pero lo anterior, no quiere decir que la nulidad de derecho público se aplique a la función que ejercen los tribunales de justicia, pues, por un lado, el acto jurisdiccional (en cualquiera de sus momentos) no es un acto de poder sino que de saber; y por otro, la misma Constitución dispone y remite a la ley el establecimiento de las responsabilidades y sanciones y, en este caso concreto, es la ley procesal la que regula y sanciona las irregularidades o vicios que acontezcan durante el curso del procedimiento. Recuérdese que es el artículo 6 de la Carta Fundamental el que expresa que la infracción de esta norma (que los órganos del Estado no sometan su acción a la Constitución y a la ley) generará las responsabilidades y sanciones que determine la ley. De esta manera, la Constitución reenvía a la ley la regulación de las sanciones y las responsabilidades en el evento que se infrinja el principio de juridicidad.

En este sentido, si los tribunales cometen irregularidades en sus resoluciones es la ley procesal la que determina los medios y la sanción aplicable a la actividad viciada, siendo desacertado aplicar la nulidad de derecho público. En efecto, el artículo 7 inciso $3^{\circ}$ no puede interpretarse tan ampliamente con el fin de afirmar que los actos procesales, los desarrollados dentro de un procedimiento determinado por la ley, puedan ser anulados en virtud de las normas que rigen la nulidad de derecho público porque la ley, específicamente la ley procesal, atribuye otra sanción para el caso en que se contravengan los derechos y garantías de los litigantes durante el procedimiento judicial.

El ámbito de aplicación de la nulidad procesal lo constituyen los actos procesales emanados del órgano jurisdiccional, especialmente las resoluciones judiciales y las actuaciones que emanan de los órganos auxiliares de la administración de justicia, cuando desde la valoración de la irregularidad cometida en el ejercicio de una actuación procesal o la inobservancia de

15 Pereira (2006) p. 19. 
algún presupuesto procesal se infiere que ha existido un perjuicio trascendente, un estado de indefensión para alguna de las partes (juicio de invalidez), situación que merece el reproche de la invalidez, siendo pertinente la declaración de ineficacia a petición de parte o de oficio.

En este contexto, se aprecia el diferente ámbito de aplicación de las nulidades referidas.

La extensión de la nulidad de derecho público a los actos jurisdiccionales no considera la autonomía del Derecho procesal. Aunque el Derecho procesal es una rama del Derecho Público, coincidiendo con la naturaleza del Derecho constitucional y del Derecho administrativo, no puede desatenderse que es una rama autónoma que tiene instituciones y principios propios que permiten explicarlo coherentemente y de manera científica ${ }^{16}$. Desconocer esta realidad es negar, por una parte, que el Derecho procesal es una rama autónoma respecto de las demás y desconocer los avances que esta ha tenido y, por otra, que la nulidad de derecho público tiene una naturaleza constitucional cuyo objeto es obtener la ineficacia de los actos que emanan de los órganos de la administración (actos administrativos) cuando estos actúan fuera de los límites que dispone el artículo 7 de la CPR.

En otras palabras, la nulidad de derecho público tiene por objeto anular actos de poder ${ }^{17}$, en cambio, la nulidad procesal sanciona la actividad procesal desarrollada irregularmente durante el procedimiento, o unitariamente al proceso, en el evento que exista un quebrantamiento de los derechos y garantías de las partes.

En virtud de la autonomía que detenta el Derecho procesal respecto del resto de las ramas jurídicas, no es posible mezclar instituciones que tienen distintos objetivos y fines, diversas características y protegen disímiles bienes jurídicos ${ }^{18}$. En este sentido, las divergencias son plausibles. La nulidad de derecho público tiene por objeto anular actos que emanan de los órganos de la administración cuando estos exceden las potestades atribuidas por la Constitución o la ley; la nulidad procesal, en cambio, busca sancionar las graves irregularidades que adolecen los actos jurisdiccionales (que emanan del órgano jurisdiccional o de los auxiliares de la administración de justicia) desarrollados en los diversos momentos jurisdiccionales.

Una abundante jurisprudencia ha resuelto con acierto las distinciones que señalamos. Así, ha afirmado que: "en el precepto del artículo 7 de la Constitución Política de la República de 1980, que consagra el principio de la legalidad de los actos de los organismos del Estado y sanciona con nulidad de derecho público a aquellos que se ejecuten al margen de la autoridad de la ley (...) preciso es señalar que las disposiciones legales que conciernen al Poder Judicial son de Derecho Público en cuanto se refieren a su organización y atribuciones, mas no lo son aquellas que regulan los trámites de los procesos, las relaciones de las partes y las actuaciones judiciales (...), que pueden dar lugar a nulidades procesales y, excepcionalmente (...) a nulidad civil”"

16 BarRios de ÁNGelis (1979) p. 79, explica que "la autonomía se funda y se manifiesta en la existencia de principios propios, tanto como en la unicidad del concepto proceso, irreproducible en conceptos de derecho sustancial. Esto significa que la interpretación no solo se desarrollará en principios de derecho público, sino que dentro de este orden general habrá principios especiales del derecho procesal".

17 Martínez (2003) p. 8.

18 En este sentido se pronuncia Romero (2003) pp. 381-385.

19 CS. 2 de mayo de 1988, RDJ., t. LXXXV, sec. 1ª, págs. 67 y ss., (también en FM., No 354, págs. 248 y ss.), (considerando $7^{\circ}$ ). En el mismo sentido, CS. 29 de agosto de 2000, Rol No 3408-1998 (cita LegalPublishing: CL/ 
En consecuencia, los actos procesales que infrinjan las normas que regulan la tramitación de los procesos (procedimientos) y a las actuaciones judiciales, no pueden ser atacados o invalidados a través del estatuto anulatorio de derecho público, sino solo por las vías que el Derecho procesal reconoce y dentro de las oportunidades que la ley dispone.

\section{LA FUNCIÓN JUDICIAL COMO ACTIVIDAD DE AUCTORITAS Y NO DE POTESTAS}

Este argumento, afirmado por Martínez Estay ${ }^{20}$ también permite llegar a la conclusión que hemos expresado precedentemente y, por otra parte, hace más sólida nuestra afirmación que la nulidad de derecho público es improcedente aplicarla contra los actos procesales defectuosos. En efecto, el fundamento al cual alude Martínez Estay es que la actividad judicial, el decir el Derecho, constituye una actividad de auctoritas y no de potestas $^{21}$.

En palabras del autor "la función jurisprudencial, o sea resolver pleitos o litigios, no es de potestas sino que de auctoritas. En nada cambia esta conclusión el hecho de que casi todas las constituciones hablen de 'poder judicial' para referirse a los jueces y su labor. Y como se comprenderá, esta conclusión resulta también aplicable a nuestra propia Constitución, la que si bien regula en su Capítulo VI al 'Poder Judicial', no por ello puede concluirse algo distinto a lo reseñado más arriba". El autor, posteriormente alude a que "asimismo, no puede confundirse el acto de creación o institución de un órgano con la función que este ejerce. En este sentido, si bien nadie puede poner en duda que en la creación del 'Poder Judicial chileno’ hay un acto de poder, más concretamente de la forma más pura de poder, el constituyente originario, parece evidente que este no crea la función jurisprudencial, o sea la de resolver pleitos diciendo el Derecho para cada caso concreto. Es más, la primera Constitución del mundo, la inglesa, tampoco creó la función jurisprudencial en Inglaterra, sino más bien fue

JUR/452/2000), (considerandos $5^{\circ}$ al $19^{\circ}$ ), CS. 22 de octubre de 2002, $F M$, $\mathrm{N}^{\circ}$ 503, sentencia $\mathrm{N}^{\circ} 11$, págs. 3086 y ss. (considerando $11^{\circ}$ ). La misma tendencia jurisprudencial que comentamos también es expuesta en la sentencia de la CA. de Valdivia, 2 de septiembre de 2009, Rol № 304-2009 (cita LegalPublishing: CL/JUR/793/2009; J55491/2009), (considerando $4^{\circ}$ ), que afirma que: "La nulidad de derecho público que se pretende, y que se funda en el artículo 7 de la Constitución Política de la República que consagra el principio de la legalidad de los actos de los organismos del Estado sancionando con nulidad de derecho público a los ejecutados con contravención a la ley, originando las responsabilidades y sanciones que la ley señala, se aplica en lo que al Poder Judicial se refiere a lo que dice relación con su organización y atribuciones, siendo improcedente impetrarla respecto de infracción de normas que regulan la tramitación de los procesos, y a las actuaciones judiciales en tales procesos, en donde solo se podrán reclamar de nulidades procesales y excepcionalmente civiles. En sentido similar pero con otros fundamentos una sentencia de la CA. de Chillán, 3 de abril de 2002, Rol № 198.561-2002, expresó que las resoluciones judiciales no pueden ser impugnadas por la vía de la nulidad de derecho público, pues, de aceptarse lo contrario "bastaría cualquier vicio procesal que acontezca durante la tramitación del juicio para impetrar la correspondiente nulidad de derecho público, haciéndose caso omiso de los recursos ordinarios o extraordinarios que franquea la ley para tales efectos. Así las cosas, la nulidad procesal y el recurso de casación en la forma carecerían de toda importancia y significación procesal y jurídica en nuestro ordenamiento jurídico" (considerando $4^{\circ}$ ). Y agrega que "no debe olvidarse que en nuestro ordenamiento civil o penal, las resoluciones judiciales solo pueden ser impugnadas mediante los correspondientes recursos procesales que señala la ley" (considerando $5^{\circ}$ ).

20 Martínez (2003) pp. 19-22.

${ }^{21}$ En esta posición se manifiesta también Pereira (2006) p. 212, al sostener que: "Efectivamente aunque se use la palabra 'poder' para designarlo, el judicial es más un caso de auctoritas que de potestas”. 
esta la que en cierto modo creó o al menos contribuyó a la creación de aquella. Y es que el fin del Derecho es la justicia, por lo que es inherente a aquel que haya alguien que lo aplique con el objeto de hacer efectivo dicho fin, a través de casos concretos, de pleitos" 22 .

Concluye el profesor Martínez señalando que "así las cosas, cuando el art. 7 de la Constitución dispone la nulidad de los actos de los órganos del Estado contrarios a esta, debe entenderse que se trata de un mecanismo destinado a hacer efectiva la finalidad de la Constitución, o sea, la limitación del poder por medio del Derecho. Y no puede olvidarse que, en último término, quienes dicen el Derecho a través de casos concretos son precisamente los jueces. Por ello, a pesar del título del Capítulo VI de nuestra magna carta, dejando de lado el excesivo formalismo que tanto daño ha hecho en nuestro país, y en consideración a que, en último término, los jueces no son 'poder', estimo que la Nulidad de Derecho Público no les resulta aplicable. En caso contrario se produciría una situación absurda, porque la Constitución y el Imperio del Derecho se estructuran en base a la existencia de un límite externo al poder, el Derecho, aplicado por entidades también externas, fuera del control del poder. Y los jueces precisamente reúnen esa cualidad, son un límite externo al poder, porque no son poder. Por ello si se les aplicase la Nulidad de Derecho Público habría que concluir que son poder, y por tanto, no habría limitaciones al poder, sino que meras autolimitaciones, lo que es ajeno a la idea misma de Constitución"23.

Este argumento nos parece del todo razonable, involucra elementos históricos y pone énfasis en la labor judicial como una actividad de auctoritas y no de potestas.

Como se sabe, la auctoritas se suele definir como "el saber socialmente reconocido" y la potestas como "el poder socialmente reconocido" 24 . La auctoritas actúa como un límite externo al poder ${ }^{25}$. En palabras de Domingo, “... el poder judicial no emana del pueblo porque no es stricto sensu un poder del Estado. En mi opinión, la expresión 'poder judicial' es una contradictio in terminis, que deriva de que el Estado moderno no ha sabido diferenciar, como ya he dicho, la autoridad del juicio -cuyo máximo exponente es la sentencia- de la potestad de su tramitación y ejecución, es decir, la ‘judicación' de la 'jurisdicción' o potestad jurisdiccional. La distinción entre autoridad y potestad, concretada procesalmente en el binomio judicación/jurisdicción, me lleva a pensar, como digo, que la expresión poder judicial es inadecuada. 'Judicial' es lo relativo al juicio, y este corresponde al ámbito del entendimiento, es decir, de la autoridad, y no del poder" 26.

De un modo concreto, a nuestro modo de ver las cosas, no es posible afirmar que la nulidad de derecho público sea aplicable a los actos jurisdiccionales, pues, en dicho caso, se confunden los órdenes en que debe actuar, toda vez que tal ineficacia es aplicable a los actos emanados de los órganos del Estado que constituyen poder y no a los actos de auctoritas que emanan precisamente de los jueces que administran justicia. La función judicial controla a los órganos de poder, limita sus actuaciones sometiéndolas al ordenamiento jurídico vigen-

\footnotetext{
22 Martínez (2003) p. 21.

23 Martínez (2003) p. 22.

24 En este sentido D’Ors (2004) p. 42. En similar sentido Gutiérrez de Cabiedes (1974) p. 46.

25 En este sentido D’Ors (2004) p. 42; Domingo (1999) p. 138; Pereira (2006) p. 213.

26 Domingo (1999) pp. 119-120.
} 
$\mathrm{te}^{27}$, lo que permite comprender la exclusión de la nulidad procesal de derecho público a los actos jurisdiccionales porque, a través de estos, no se ejerce un poder sino que una labor de control de los actos ejecutados por quienes detentan el poder.

En otras palabras, si la nulidad de derecho público tiene por objeto anular los actos de poder, entonces, esta no puede aplicarse a una actividad de auctoritas, como resulta ser la actividad jurisdiccional, la función de administrar justicia, quedando vedado afirmar que esta sanción es aplicable a los actos jurisdiccionales.

\section{LA INFRACCIÓN DEL PRINCIPIO DE LEGALIDAD}

Otro argumento para sostener la inaplicabilidad de la nulidad procesal de derecho público a los actos jurisdiccionales, se basa en que de aplicarse esta especial sanción se transgrede el principio de legalidad.

En términos generales, el principio de legalidad impone el deber a todos los órganos del Estado de actuar dentro del ordenamiento jurídico y en el ámbito de su competencia (art. 6 y 7 CPR).

En el ámbito del proceso, el principio de legalidad puede analizarse desde dos vertientes, a saber: la legalidad como base fundamental de la administración de justicia y la legalidad desde el punto de vista funcional o procedimental.

En cuanto base fundamental de la administración de justicia, el principio de legalidad se manifiesta en que solo en virtud de una ley se puede establecer un tribunal y determinar su competencia. En efecto, solo la ley puede determinar la organización y atribución de los tribunales de justicia ${ }^{28}$. La carta fundamental reconoce expresamente este principio en el artículo 77 inciso $1^{\circ} \mathrm{CPR}$.

Desde el punto de vista procedimental, el principio de legalidad se manifiesta en que la actividad de los tribunales y de las partes debe ceñirse a la ley, siendo un elemento del debido proceso que toda sentencia de un órgano que ejerza jurisdicción provenga de un proceso legalmente tramitado (art. $19 \mathrm{No}^{\circ} 3,63 \mathrm{~N}^{\circ} 2$ y 3 CPR).

En cuanto a la legalidad de los medios para obtener la declaración de nulidad, pueden utilizarse todos los mecanismos o instrumentos que el Derecho procesal pone a disposición de las partes o del juez para lograr tal declaración, debiendo ejercerse dentro de las oportunidades que correspondan. Así, en general, se podrán utilizar tanto los medios directos como indirectos que tengan por objeto conseguir aquella declaración.

La jurisprudencia reconoce la aplicación de este principio al indicar lo siguiente: " 8 . Que, efectivamente, la anulación de los actos que llevan a cabo los tribunales en ejercicio de la potestad

\footnotetext{
27 Al respecto, Domingo (1999) pp. 93-94, señala que: "aunque no la única, es función principal de la autoridad servir de límite de la potestad, de límite natural, podríamos decir, pues la autoridad tiene una naturaleza distinta de la potestad. Esta autoridad limitadora, por su parte, no conoce más límites que el personal del grupo social que la reconoce. Para poder 'autorizar' (refrendar) o 'desautorizar' (censurar) los actos de la potestad, es necesario (...) que la autoridad permanezca funcionalmente separada de la potestad, pues, si aquella queda vinculada a esta, deja de ser un límite externo. Pero este límite no es freno, impedimento material, ya que la autoridad en modo alguno puede ejercer una fuerza que no tiene; de ahí que no le sean propios los actos de ejecución, sino solo los de advertencia”.

28 Así lo explica cfr. Oberg y Manso (2008) pp. 73 y 74; Lorca (1993) pp. 44-46.
} 
jurisdiccional del Estado, debe perseguirse a través de los medios que franquea la ley procesal y que, sustancialmente, consisten en la declaración de nulidad de oficio o a petición de parte, que contemplan los artículos 83, 84 y 85 del Código de Procedimiento Civil, así como en los recursos de casación y revisión que regulan, respectivamente, los Títulos XIX y XX del Libro III del mismo texto y las normas pertinentes del Código de Enjuiciamiento Penal, o bien, excepcionalmente, por medio del ejercicio de las facultades disciplinarias de los Tribunales Superiores, conforme el artículo 545 del Código Orgánico de Tribunales. 9º. Que de esta suerte, de la nulidad de los actos jurisdiccionales pronunciados con infracción del artículo $7^{\circ}$ de la Constitución vigente, no podría reclamarse, en su caso, sino por las vías que contemplan dichas normas procesales, pues el sistema jurídico nacional no establece otros medios de impugnar los defectos de que pueden adolecer los procedimientos judiciales y los vicios de forma o de orden sustantivo que pueden afectar las resoluciones de los tribunales" 29.

La doctrina también se ha pronunciado en similar sentido. En efecto, Ortúzar Latapiat comentando un fallo sostiene que: "Una sentencia puede ser atacada por la vía de la nulidad procesal, lo que como en forma reiterada ha decidido esta Corte Suprema, debe hacerse precisamente en el mismo proceso en que se dictó el fallo, sin que sea lícito discutir su validez en un juicio diverso posterior, porque tal debate importaría, en el fondo, que un recurso de casación puede interponerse contra una resolución ejecutoriada". Continúa el mismo autor afirmando que "respecto del fallo ejecutoriado que ha puesto término a un procedimiento jurisdiccional menos cabe entablar una acción de 'nulidad de derecho público', como la intentada en estos autos, que se hace derivar, básicamente, del artículo $7^{\circ}$ de la Constitución, que si bien enuncia el principio de legalidad, al que también está sujeta la función jurisdiccional, no autoriza deducir una acción

29 CS. 10 de julio de 2001, Rol N 337-1998 (Cita LegalPublishing: CL/JUR/260/2001; 19092), (considerandos $8^{\circ}$ y $9^{\circ}$ ) (el destacado es nuestro). En este mismo sentido, CS. 29 de agosto de 2000, Rol N ${ }^{\circ} 3408-1998$ (cita LegalPublishing: CL/JUR/452/2000), (considerandos $8^{\circ}$ y $9^{\circ}$ ), CS. 2 de mayo de 1988, RDJ., t. LXXXV, sec. $1^{\text {a }}$, págs. 67 y ss., (también en FM., No 354, págs. 248 y ss.), (considerando $5^{\circ}$ ). Más recientemente la CA. de Copiapó, 17 de junio de 2008, Rol N² 272-2007 (cita LegalPublishing: 39247), ha sostenido la misma doctrina al disponer que: "En efecto, como lo ha declarado de manera unívoca la Jurisprudencia de nuestros tribunales: "Los vicios que pueden producirse en los juicios solo cabe remediarlos a través de los recursos procesales que las leyes conceden, que deben hacerse valer en el mismo juicio, en los términos y formas pertinentes, pues no existe disposición legal alguna que permita anular las actuaciones de otro procedimiento, cualquiera que sea su naturaleza, por medio de otro juicio ordinario. Tal doctrina, apoyada también en normas expresas contenidas en los artículos 80, 82, 84 y 85 del Código de Procedimiento Civil, entre otros, concluye, en síntesis, que la inamovilidad de los actos judiciales se encuentra garantizada en la Constitución. Las infracciones de orden jurídico procesal se sancionan por la legislación que las rige. El Mensaje con que se sometió a la aprobación del Congreso nuestro Código Civil confirma que las normas sobre nulidad que este contempla se refieren a 'los contratos y demás actos voluntarios que constituyen derechos' y a las personas que los acuerden, pero no a los juicios, salvo los casos que el mismo Código así lo dispone, como en el artículo 1348 tratándose de particiones. Salvo norma expresa, la nulidad de los actos de un poder público en general no se regla por las normas del Derecho Privado. Si se aplican los principios del Código Civil, se atentaría contra la inmutabilidad de las decisiones del Poder Judicial destruyéndose por su base la institución de la cosa juzgada. Al constituir el proceso un encadenamiento de actuaciones y resoluciones, la nulidad absoluta de cualquiera de ellas daría margen para demandar restituciones en cualquier tiempo, más allá de los plazos procesales e, incluso, después de cumplido un fallo. Las infracciones procesales pueden remediarse por los recursos ordinarios que contempla la ley del ramo y también mediante sanciones. Todo esto ha conducido a resolver que las nulidades de derecho procesal deben plantearse in limine litis esto es, dentro del mismo procedimiento y ante el mismo tribunal en que ella se haya producido". 
de nulidad contra una resolución judicial en un procedimiento diverso de la causa en que ella se pronunció. La anulación de los actos de los tribunales debe perseguirse a través de los medios que franquea la ley procesal (...) De tal modo, la nulidad de los actos jurisdiccionales pronunciados con infracción del artículo $7^{\circ}$ de la Constitución vigente, no podría reclamarse, sino por las normas que franquean dichas normas procesales, ya que el sistema jurídico nacional no establece otros medios de impugnar los defectos de que puedan adolecer los procedimientos judiciales o los vicios de forma o de orden sustantivo que puedan afectar las resoluciones de los tribunales" 30 .

En consecuencia, quienes afirman la aplicación de la nulidad procesal de derecho público a los actos jurisdiccionales, no visualizan la infracción de un principio básico de la administración de justicia, como lo es la legalidad, razón por la cual, concluimos que esta sanción especial es inaplicable a los actos jurisdiccionales irregulares.

\section{LA HISTORIA FIDEDIGNA DEL ESTABLECIMIENTO DEL CÓDIGO DE PROCEDIMIENTO CIVIL}

La historia fidedigna del establecimiento del Código de Procedimiento Civil también resulta útil para afirmar que es improcedente aplicar la nulidad procesal de derecho público a los actos jurisdiccionales defectuosos.

Para comprobar lo anterior basta revisar la sesión 89, de 20 de junio de 1879, de la primera Comisión Revisora del Proyecto de Código de Procedimiento Civil de 1884, en la cual sus miembros discutían lo siguiente: “... Con motivo de este acuerdo pregunta el señor Gandarillas si se conserva la acción ordinaria de nulidad contra las sentencias pronunciadas en virtud de falsas pruebas. El señor Campillo es de opinión que no debe considerarse subsistente esa acción, porque conviene revestir de toda fuerza i estabilidad la cosa juzgada. (...) Opinando como el señor Campillo i a fin de evitar dudas, propone el señor Gandarillas se diga espresamente que no se concedan contra las sentencias otros recursos que los establecidos por la lei. Lira acepta esta indicación i observa que tal vez puede tener cabida más oportuna en otro título del Proyecto. El señor Campillo prefiere este lugar, porque aquí se trata del único recurso que la lei concede para invalidar sentencias. El señor Ministro quiere que, no solo se diga en términos generales que la lei no concede otros recursos, sino que categóricamente se esprese que no admite la acción ordinaria de nulidad contra las sentencias. Se acordó agregar al fin del título un artículo en que se esprese que el recurso de casación de que aquí se trata es el único medio que la lei concede para invalidar sentencias" 31 .

Sin embargo, ese artículo posteriormente se suprimió porque “... era tan evidente la verdad de su contenido que él se hacía innecesario”32, pero por tal razón no puede pensarse que existió un cambio de opinión, pues, ello quedó plasmado en el Mensaje del Código de Procedimiento Civil.

\footnotetext{
30 Ortúzar (2000) pp. 6 y 7 (el destacado es nuestro). En el mismo sentido cfr. Muñoz (2001) pp. 1-2.

31 Proyecto de Código de Enjuiciamiento Civil (1884) pp. 372 y 373 (el destacado es nuestro).

32 Así lo sostiene Santa Cruz (1936) pp. 102-103.
} 
En efecto, el Mensaje de 1 de febrero de 1893, con que el presidente de la República don Jorge Montt, remitió al Congreso el proyecto del Código de Procedimiento Civil señala que: "terminan los procedimientos especiales con el que debe servir para el recurso de casación en la forma y en el fondo. No difiere el primero sustancialmente del actual recurso de nulidad, pero se ha procurado llenar los vacíos del actual y aclarar las dudas que en él se notan. Se determinan los trámites cuya omisión da lugar al recurso, y se desconoce de un modo expreso la acción ordinaria de nulidad para invalidar sentencias, no admitiéndose otro camino que el de la casación para lograr este resultado; en obsequio a la brevedad de los procedimientos y al tranquilo goce de los derechos declarados en juicio"33.

Este argumento histórico, generado el 20 de junio de 1879, debe comprenderse bajo la vigencia del artículo 160 de la Constitución de 1833 (actual inciso $2^{\circ}$ y $3^{\circ}$ del art. 7 $\mathrm{CPR}$. Entonces, como se comprenderá, la interpretación que hizo la Comisión Revisora, respecto de la forma de obtener la nulidad de una resolución judicial, excluye al menos implícitamente, que esta pueda ser anulada a través de la nulidad de derecho público, pues, la única forma de lograr la nulidad del acto jurisdiccional es, finalmente, a través del recurso de casación, excluyéndose expresamente la acción ordinaria de nulidad, razón que excluye la acción de nulidad de derecho público ${ }^{34}$.

Por otra parte, dentro de este mismo argumento histórico, cabe remontarse aún más atrás, y preguntarse lo siguiente: la doctrina clásica de la nulidad de derecho público afirma que en el pensamiento de don Mariano Egaña la nulidad de derecho público, dispuesta en su voto particular, operaba de pleno derecho y era aplicable contra los actos jurisdiccionales, ¿para qué posteriormente el mismo Egaña preparó un proyecto de Código de Procedimiento Civil que, en una de sus partes, dio lugar a la Ley Mariana sobre recurso de nulidad de 1 de marzo de 1837?; ¿Acaso esta ley no estaría de más, pues, bastaría invocar la Constitución para efectos de lograr la nulidad de la actividad procesal viciada o defectuosa?; ¿No habrá sido otra la intención de don Mariano Egaña?

En consecuencia, en nuestra opinión, la historia fidedigna del establecimiento del Código de Procedimiento Civil es concluyente, la cual nos permite afirmar que es improcedente impetrar la acción ordinaria de nulidad con el objeto de anular sentencias, acción ordinaria que podría ser fundada tanto en razones de carácter civil como de derecho público.

De afirmarse que contra un proceso terminado por sentencia ejecutoriada pueda posteriormente impetrarse, a través de un procedimiento ordinario o sumario, una acción de nulidad procesal de derecho público ${ }^{35}$ constituye una flagrante infracción a la historia fidedigna del establecimiento de nuestro Código de Procedimiento Civil, pues, ello im-

33 Cfr. Mensaje del Código de Procedimiento Civil de 24 de noviembre de 1942 enviado por el presidente de la República don Juan Antonio Ríos a los conciudadanos del Senado y de la Cámara de Diputados.

34 En este sentido Marín (2004) p. 153, quien afirma que “... los antecedentes de la historia del Código de Procedimiento Civil demuestran que al establecerse los recursos de casación, justamente, se excluyó toda posibilidad de intentar acciones sustantivas de nulidad en contra de sentencias judiciales. Esto, naturalmente, no significa que los tribunales, que son órganos del Estado, estén al margen del principio de legalidad de la acción del Estado que establecen los artículos $6^{\circ}$ y $7^{\circ}$ de la Constitución, solo que la forma de reclamar de los vicios en que incurran al contravenir las normas que rigen su actuación, son las propias de la nulidad procesal y no una acción autónoma de nulidad de derecho público".

35 Esta afirmación la hace OTERO (2009) p. 271. 
portaría reconocer que existe una acción autónoma de nulidad para invalidar actuaciones judiciales (acción de nulidad procesal de derecho público), cuestión que expresamente el mensaje del Código desconoce desde hace más de 110 años y que, según lo demuestra la historia fidedigna del establecimiento del Código, de más de 130 años, tal posibilidad se proscribió expresamente, según se explicó.

En consecuencia, en virtud de este argumento también podemos concluir que la nulidad de derecho público es inaplicable contra el acto jurisdiccional.

\section{LA TRANSGRESIÓN DE LA COSA JUZGADA}

La doctrina afirma que la nulidad procesal de derecho público es imprescriptible y de esta proposición, algunos expresan que esta puede utilizarse para atacar los actos jurisdiccionales en cualquier momento del juicio, incluso una vez que este ha concluido por sentencia firme ${ }^{36}$. Esta proposición tiene varios inconvenientes que pasaremos a explicar y que nos permitirán sumar un nuevo argumento para afirmar la improcedencia de servirse de la denominada nulidad procesal de derecho público para invalidar los actos jurisdiccionales viciados.

La cosa juzgada constituye un mecanismo procesal que cierra o clausura un proceso, un límite que impide a las partes y al juez modificar lo resuelto en una determinada resolución judicial ${ }^{37}$. Desde que se logra este efecto, las sentencias definitivas e interlocutorias firmes ya no pueden ser alteradas, modificadas ni revocadas en cuanto al fondo porque no existen más instrumentos procesales que permitan continuar conociendo del asunto. Esto es sin perjuicio de la respectiva acción de revisión que puede impetrarse contra las sentencias firmes con el objeto de lograr la revocación de las mismas fundado en diversas conductas ilícitas constitutivas de fraude procesal o en haber sido dictada contra otra sentencia pasada en autoridad de cosa juzgada (art. $810 \mathrm{~N}^{\circ} 1$ al 4 CPC); y del incidente especial de nulidad por falta de emplazamiento, el cual puede entablarse incluso una vez que el fallo se encuentra firme o ejecutoriado (arts. 80, 182 inc. $2^{\circ}$ y 234 inc. $4^{\circ} \mathrm{CPC}$ ).

De esta manera, afirmar que la acción de nulidad procesal de derecho público que tiene por objeto atacar resoluciones dictadas en el ejercicio de la jurisdicción, es imprescriptible, pugna con las instituciones básicas de la actividad jurisdiccional. En efecto, la imprescriptibilidad de la acción referida importaría poder deducirla contra una sentencia firme, vulnerando el efecto de cosa juzgada que adquirió tal resolución, infringiendo una institución de orden público que constituye uno de los pilares fundamentales del régimen jurídico al asegurar la certidumbre y estabilidad de los derechos que ella consagra ${ }^{38}$.

\footnotetext{
36 Así lo sostienen Otero (2009) pp. 263 y 271; Soto (2009) p. 433.

37 En este sentido TAPIA (2000) p. 135, afirma que: "en todos los tiempos y en todos los ordenamientos jurídicos se ha sentido la necesidad de establecer unos límites y unos efectos a la controversia ya resuelta, de modo que la decisión firme sobre ella sea garantizada en lo sucesivo, con la consecuente seguridad jurídica que a los justiciables proporciona la indiscutibilidad de lo ya resuelto. La institución de la cosa juzgada, ínsita en la propia función jurisdiccional ('juzgar' con carácter irrevocable), contribuye a la paz social; porque no es conveniente que lo que ya ha sido discutido y resuelto por los órganos jurisdiccionales vuelva a ser removido de nuevo".

38 En este sentido se ha pronunciado la jurisprudencia, cfr. por todas CS. 14 de mayo de 1955, RDJ., t. LII, sec. $1^{\text {a }}$, pp. 99 y ss. Esta sentencia profundiza en la idea que una vez que el proceso ha fenecido en virtud de la cosa juzgada es imposible atacarlo a través de la nulidad salvo la hipótesis de revisión. La sentencia reconoce el
} 
Los partidarios de la nulidad procesal de derecho público indican que no se produce un atentado contra la cosa juzgada, pues, las sentencias que adolecen de vicios como la falta de observancia de las normas de procedimiento y la vulneración del debido proceso constituyen “... sentencias inexistentes, por cuanto si el proceso es nulo, la sentencia es igualmente nula y no puede producir efecto legal alguno, por lo cual jamás se ha materializado la cosa juzgada" 39 .

Discrepamos de la opinión anterior, porque la realidad del proceso implica justamente sostener lo contrario. En efecto, si el proceso se desarrolla sin la observancia de las normas de procedimiento o infringiendo el debido proceso, no quiere decir que ese proceso no exista. Esto es un error del cual parte la doctrina de la nulidad de derecho público y su aplicación ipso iure, pues, no puede afirmarse que frente a las infracciones anteriores, las sentencias dictadas sean inexistentes porque realmente existen, tienen vida jurídica y producen los efectos que la ley determina ${ }^{40}$.

Desde otra perspectiva, la doctrina que defiende la aplicación de la nulidad de derecho público contra los actos jurisdiccionales confunde dos categorías jurídicas que conviene distinguir como son la inexistencia de la nulidad. Ellos aluden a que la sentencia pronunciada en un proceso que adolece de los vicios mencionados es inexistente para luego sostener que el proceso es nulo, por tanto, la sentencia es igualmente nula y no puede producir

carácter constitucional de la cosa juzgada al disponer, en su considerando $10^{\circ}$ : "Que cuando la Constitución Política del Estado en su artículo 80 dispone que 'Ni el Presidente de la República ni el Congreso pueden, en caso alguno, hacer revivir procesos fenecidos, consagra la inmutabilidad de los derechos adquiridos en juicio como efecto de la institución de la cosa juzgada. Su finalidad es hacer respetar esos derechos, especialmente el de propiedad, en el que se sustenta la organización política, económica y jurídica de la nación, si bien con las limitaciones que la misma Constitución establece. En suma, la cosa juzgada es una institución de orden público y constituye uno de los fundamentos necesarios del régimen jurídico al asegurar la certidumbre y estabilidad de los derechos que ella consagra”. En el proceso que dio lugar a la sentencia cuyos extractos exponemos, se solicitó la declaración de inaplicabilidad de un precepto legal que permitía oponer excepciones una vez que el proceso se encuentra fenecido, lo que importaría la inconstitucionalidad del recurso de revisión porque vulneraría la cosa juzgada. Al respecto, aunque disentimos en cuanto a la naturaleza jurídica que se atribuye aquí a la revisión, el fallo afirmó, en el considerando $12^{\circ}$ y siguientes: "Que se dice que si la prohibición de revivir procesos fenecidos importase un reconocimiento constitucional de la cosa juzgada, el recurso de revisión sería inconstitucional. No es así. Lo que se prohíbe es el acto posterior al proceso que autorice a reabrirlo; lo expresan las palabras 'revivir' y el participio pasado 'fenecido' empleados en el artículo 80 de la Constitución. La 'revisión', en cambio, se efectúa con arreglo a la ley anterior al fallo; es un recurso más, dentro del procedimiento, como la apelación o la casación. El proceso no fenece para este efecto mientras haya plazo pendiente para interponer el recurso, porque la revisión forma parte del estatuto jurídico con arreglo al cual se pronunció la sentencia. $13^{\circ}$ Que la revisión es un recurso excepcional que se justifica en razón de que el fallo que se anula por este medio extraordinario pugna con otras decisiones judiciales también ejecutoriadas, o se funda en un error notorio que causa una injusticia manifiesta que debe repararse". En idéntico sentido, CS. 9 de mayo de 1958, RDJ., t. LV, sec. $1^{\mathrm{a}}$, págs. $71 \mathrm{y}$ ss. (considerandos $6^{\circ}, 8^{\circ}$ y $9^{\circ}$ ).

39 ОтеRо (2009) pp. 267-271. El autor explica que: "el proceso jurisdiccional que adolece de un vicio procesal de derecho público es nulo por mandato constitucional y, en consecuencia, no puede ser validado en forma alguna, dado que la norma constitucional que establece la nulidad persigue una finalidad muy superior al interés particular, cual es la protección del Estado de Derecho”. Ibid., pág. 270.

40 Incluso, las hipótesis de cosa juzgada aparente son reconducidas por el Código de Procedimiento Civil a una hipótesis de nulidad procesal. Así ocurre por ejemplo, con un proceso que sigue adelante no obstante haberse emplazado defectuosamente al demandado, quien, en su oportunidad podrá deducir el incidente de nulidad por falta de emplazamiento del art. 80 del CPC. 
efecto legal alguno, por lo cual, jamás se ha materializado la cosa juzgada. Tal afirmación contiene una contradicción evidente, pues, no es correcto sostener que la sentencia es inexistente y luego señalar que el proceso es nulo y, como tal, la sentencia también es nula y que, por esa razón, no hay cosa juzgada.

Para aclarar lo anterior, es necesario expresar que un proceso y su correspondiente sentencia pueden ser anulados por los medios que franquea la ley procesal y que mientras estén en potencia de ser anulados producen los efectos que la ley dispone. Tales efectos generados por la actividad jurisdiccional solo desaparecerán en virtud de una declaración judicial de ineficacia, es decir, mediante una resolución judicial que disponga la nulidad y, en consecuencia, elimine los efectos generados por la actividad procesal irregular. No es posible sostener que una sentencia sea nula sin previa declaración judicial porque la nulidad debe ser judicialmente declarada y así se explica todo el sistema anulatorio procesal, el cual desconoce la nulidad ipso iure.

Por otra parte, el hecho de haber infringido las normas de procedimiento o, en su caso, el debido proceso no quiere decir que un acto jurisdiccional no exista. En efecto, se parte de la base que quien juzga tiene potestad jurisdiccional, por lo tanto, los actos que dicte el juez existen y generan efectos. Entonces, ¿por qué se sostiene que son inexistentes? A nuestro parecer, esos actos viciados existen, tanto así que producen efectos porque tienen una apariencia de juridicidad los cuales se pretenden eliminar a través de la declaración judicial de nulidad. No se pretende una declaración judicial de inexistencia, con lo cual descartamos que el acto jurisdiccional no exista, pues, en la práctica resulta que existe y, tanto es así, que los efectos que produce quieren ser eliminados del proceso a través de la declaración de ineficacia.

También nos preguntamos ¿por qué la doctrina sostiene que el acto es inexistente?, ¿acaso debiera decirse que se trata de aplicar la inexistencia y no la nulidad?, ¿cómo se pasa de un acto nulo a uno inexistente?, ¿si fuese inexistente, no habrá querido decirlo expresamente el constituyente?

La contradicción es manifiesta y huelgan mayores comentarios.

Ahora, a mayor abundamiento, veamos un ejemplo práctico: si un procedimiento se inició como ordinario, no obstante que de acuerdo a la naturaleza de la acción deducida debió tramitarse según las reglas del procedimiento sumario, ello no puede llevar a sostener que el proceso y que la sentencia definitiva firme que resolvió la controversia son inexistentes. Es de toda lógica jurídica que tales actos jurisdiccionales existieron por lo que no es efectivo afirmar que no existen. Por cierto que la actividad procesal viciada puede ser anulada -insistimos que por las vías procesales- pero mientras no lo sea, se presume válida y es eficaz en virtud del principio de conservación de los actos procesales.

La jurisprudencia es ilustradora en este sentido, pues, ha declarado que la inobservancia del presupuesto procesal de adecuación del procedimiento a la acción deducida en juicio puede importar una convalidación tácita que impide controlarlo con posterioridad ${ }^{41}$.

\footnotetext{
41 En este sentido, la CS. 25 de octubre de 1963, RDJ., t. LX, sec. 1a, pp. 316 y ss. (también en FM., N 59, octubre, 1963, págs. 216-217), expresó que “... en la realidad, en dicho recurso solo se plantea un problema de carácter procesal, cual es el de decidir si los jueces recurridos se encontraban facultados para invalidar de oficio
} 
Evidentemente que si la inadecuación del procedimiento aplicado genera un atentado grave contra los derechos y garantías de las partes, entonces el camino para invalidar la sentencia es a través de la nulidad, pero no la de derecho público, sino que la nulidad procesal, y así se ha declarado ${ }^{42}$.

Por otro lado, consideramos que el mismo concepto de jurisdicción ${ }^{43}$ involucra aquel poder deber del Estado de que sus órganos jurisdiccionales administren justicia y que lo resuelto en definitiva tenga valor o eficacia de cosa juzgada ${ }^{44}$, es decir, que dicha decisión, desde la teoría procesalista moderna de la cosa juzgada sea inmutable o inalterable ${ }^{45}$, inimpugnable y coercible. Por otra parte, si se niega que exista un límite temporal en el procedimiento para declarar inválida la actividad procesal, se está negando el concepto y las características de la jurisdicción, una de las cuales es la cosa juzgada ${ }^{46}$.

todo lo actuado en la causa, a pretexto de que se habría incurrido en un vicio de nulidad al tramitar y resolver en forma incidental la petición de caducidad de las pertenencias mineras (...), por no haberse tramitado en la forma que determina el artículo 197 del Cód. de Minería. Las formalidades que establece la ley de la actuación, en general, obedecen al propósito de resguardar los derechos de las partes, a fin de que dentro del proceso dispongan de medios eficaces para hacer valer sus derechos; y es por ello, que salvo los casos en que se produzca una nulidad de orden público, como serían las provenientes de la incompetencia absoluta del Tribunal, o de la falta de capacidad de las partes, todo vicio debe ser reclamado por el afectado, y si así no se hace en la oportunidad que señala la ley, el defecto queda saneado, y por lo mismo, no es dable a los tribunales substituir la actividad de las partes, y declarar oficiosamente nulidades no reclamadas. De los antecedentes aparece que esto es precisamente lo ocurrido en el juicio a que se refiere la queja, puesto que los contendientes se allanaron a tramitar en forma incidental la antes referida petición de caducidad, por lo que es manifiesto que los jueces recurridos hicieron mal uso de sus atribuciones, al invalidar en las condiciones señaladas un procedimiento que, en el supuesto de que hubiese adolecido de algún vicio de nulidad, quedó convalidado por la aquiescencia tácita de las partes interesadas".

42 En este sentido y fundado especialmente en la restricción del derecho de defensa, CA. de Santiago, 19 de marzo de 2002, RDJ., t. IC, sec. 2a a págs. 20-21, declaró la nulidad de la sentencia en la parte que iniciado un juicio especial hipotecario regido por el procedimiento contenido en la Ley General de Bancos, también se demandó el cobro de un pagaré, el cual debe demandarse de acuerdo a las reglas generales del juicio ejecutivo contenido en el título I del Libro III del Código de Procedimiento Civil. En el considerando $2^{\circ}$ se indica: "2。 Que, en consecuencia, respecto de ese pagaré, se ha seguido un procedimiento que no es el definido por la ley, lo que afecta al debido proceso. Se trata de normas de orden público y que, además, otorgan al ejecutado mayores garantías de defensa, todo lo cual hace procedente la declaración de nulidad procesal respecto de lo obrado en relación con ese pagaré".

43 Cfr. Montero (2011), pág. 474, afirma que: "el efecto más importante del proceso es la cosa juzgada, tanto que la existencia de la misma es elemento determinante de la jurisdicción, lo que justifica su estudio detenido".

${ }^{44}$ En este sentido Nieva (2006) p. 119, afirma que: “... la seguridad jurídica requiere que sobre cada asunto solamente pueda decidirse una única vez. La jurisdicción existe para dar fijeza y seguridad a las relaciones humanas conflictivas. Si hoy se determinó que existió un hecho delictivo, no es aceptable que mañana el mismo juez que dictó la sentencia, o cualquier otro juez, digan que ese hecho nunca existió, simplemente porque, en ese caso, los litigantes ya no sabrían a qué atenerse y, por otra parte, el sistema correría el riesgo de entrar en una total corrupción y falta de seriedad que, sin duda, acabarían con él".

45 Sobre las teorías que explican el efecto de la cosa juzgada y cómo han sido recogidas por nuestra jurisprudencia cfr. Romero (2002) pp. 11-18 y 41-91. También cfr. Romero (2001) pp. 788 y 789; PereirA (1954) pp. 32-43; NieVA (2006) pp. 46-58; Montero (2011) pp. 479-481.

46 Sobre la cosa juzgada como característica de la jurisdicción, entre otros, cfr. Hoyos (2001) p. 25; Colombo (1968) pp. 34-35; López (1987) p. 83; Galté (1954) pp. 108 y 109; Couture (2011) pp. 30-33, LozanoHiguero (1990) p. 89. 
A mayor abundamiento de lo expuesto, la mayoría de la doctrina afirma que la cosa juzgada constituye la causa extrema de subsanación de las nulidades en el proceso ${ }^{47}$. En efecto, si la nulidad procesal es una forma de invalidez de los actos procesales, parece lógico que esta solo pueda impetrarse mientras exista juicio pendiente (in limine litis) y antes que la resolución judicial que se pretende impugnar o invalidar adquiera el efecto de cosa juzgada, pues, será imposible impetrar la declaración de nulidad en forma posterior, quedando convalidados la mayoría de los vicios que pueda padecer la actividad procesal.

Bajo esta proposición no puede afirmarse que impetrando la nulidad procesal de derecho público se pueda anular un proceso terminado por sentencia firme. En otras palabras, los vicios o defectos que adolezcan los actos procesales deben ser denunciados in limine litis, esto es, mientras exista proceso pendiente. Las partes, el juez y cualquier otra persona interesada en esa relación jurídica (legitimada), una vez que los actos alcanzaron valor o eficacia de cosa juzgada, estarán impedidos de alegar o impugnar los eventuales vicios, quedando estos convalidados, salvo que el defecto o vicio sea constitutivo de alguna de las causales de la acción de revisión (art. 810 CPC) o importe la falta de emplazamiento (art. 80 CPC).

Lo que afirmamos es reconocido por la jurisprudencia ${ }^{48}$ la cual, entre otras sentencias, sostiene que: “(...) la regla general en la materia es la de que la nulidad debe pedirse y que el vicio queda saneado si las partes no lo reclaman dentro del juicio - in limine litispor medio de los recursos y dentro de los plazos que establece la ley (...). La autoridad de cosa juzgada impide que una vez ejecutoriada la sentencia pueda discutirse la corrección o legalidad de los actos del proceso que le sirvieron de base, salvo por medio del recurso de revisión en sus respectivos casos” ${ }^{49}$.

47 En este sentido Pereira (1954) p. 103; Hernández (1995) p. 113; Chiovenda (1977) p. 102; Vergé (1987) pp. 31 y 43; Calamandrei (1973) pp. 296 y ss. En contra Morón (1957) pp. 166 y ss.

${ }^{48}$ Así, por ejemplo, la sentencia dictada por la CS. 6 de abril de 1939, RDJ., t. XXXVII, sec. 1a, págs. 1-3, en el considerando $2^{\circ}$, dispone que: "las razones que dan vida a la institución de la autoridad de cosa juzgada, una vez agotados los recursos legales para enmendar los posibles errores de fallos, sirven a favor de la sentencia buena y para mantener la errónea; de manera que el juez, llamado a resolver la cuestión ya juzgada, no tiene para que estudiar si la sentencia anterior tiene defectos de forma o de fondo, sino limitarse a saber si existe o no, y si entre los dos juicios se presentan identidades de partes, de cosa pedida y de causa de pedir"; CS. 4 mayo 1990, RDJ., t. LXXXVII, sec. $1^{\mathrm{a}}$, págs. 21-30, en el párrafo $3^{\circ}$ del considerando $14^{\circ}$ señaló que "el sistema chileno no autoriza ventilar la nulidad procesal en un nuevo proceso, salvo el caso de la acción de revisión, motivo por el cual quien lo intente como conflicto de intereses de relevancia jurídica, que otorga acción para impetrarla por la vía de un nuevo proceso, está vulnerando los artículos 5, 109 y 112 del Código Orgánico de Tribunales”; CA. de Antofagasta, 15 enero 1993. RDJ., t. XC, sec. $2^{\text {a }}$, págs. 9-11, la cual en su considerando $2^{\circ}$ sostuvo "que cabe decir que las nulidades procesales deben alegarse in limine litis, ya que la ley concede 'a las partes' oportunidades y términos dentro de los cuales pueden hacerse valer. Por tal razón la acción ordinaria de nulidad para invalidar actuaciones de un juicio es absolutamente improcedente"; CA. de Punta Arenas, 28 de mayo de 1993, RDJ., t. XC, sec. 2a, págs. 74-76, aunque refiriéndose especialmente a la incompetencia absoluta de un juez partidor, dispuso que "la nulidad pertinente puede invocarse en cualquier momento del proceso, hasta que surja la autoridad de cosa juzgada". También véase CS. 26 diciembre 1989, RDJ., t. LXXXVI, sec. $1^{\text {a }}$, págs. 151 y ss. (considerando $3^{\circ}$ ).

49 CS. 11 de noviembre de 1955, RDJ., t. LII, sec. $1^{\text {a }}$, págs. 362 y ss. (considerando 6). También resulta muy ilustrativo el considerando $5^{\circ}$ de la misma sentencia, segundo párrafo, al afirmar que: "pero cualquiera que sea el criterio que se adopte acerca de la prevalencia en las disciplinas procesales de una u otra rama del derecho, no es posible desconocer que las leyes de la actuación están dirigidas en el sentido de mantener la inmutabilidad de lo actuado y resuelto por los tribunales en el ejercicio de su potestad jurisdiccional, y de considerar como inamovibles las resoluciones judiciales, una vez pasadas en autoridad de cosa juzgada. No es permitido, entonces, 
De lo dicho podemos afirmar que dentro del proceso no existen hipótesis de nulidades que son imprescriptibles. En consecuencia, los actos jurisdiccionales y el proceso mismo -este pendiente o ejecutoriado- solo pueden atacarse por las vías que el Derecho procesal establece y dentro de las oportunidades que dispone la ley. Así, la denominada nulidad procesal de derecho público es improcedente aplicarla contra los actos jurisdiccionales viciados por infracción de normas de procedimiento o disposiciones del debido proceso, pues, ni la Constitución ni la ley establecen explícitamente su aplicación a los actos procesales.

Pretender utilizar el estatuto de la nulidad de derecho público o nulidad procesal de derecho público contra una resolución judicial viciada que está firme, fundado en el carácter imprescriptible de la misma sanción, atenta contra la cosa juzgada, la seguridad jurídica y vulnera el estatuto jurídico que explica e informa el sistema anulatorio de la actividad procesal irregular.

\section{LA TRANSGRESIÓN DE LOS LÍMITES DEL SISTEMA ANULATORIO QUE IMPIDEN DECLARAR LA NULIDAD DE DERECHO PÚBLICO}

Precedentemente nos hemos referido a aquellos casos en que en un juicio se pronuncia una sentencia definitiva o interlocutoria firme que produce cosa juzgada (arts. $174 \mathrm{y}$ 175 CPC) y concluimos que en tales hipótesis es inaplicable la nulidad procesal de derecho público para obtener la ineficacia de los actos jurisdiccionales porque se infringe un atributo propio de la jurisdicción como es la cosa juzgada.

Sin embargo, hemos omitido aquellas hipótesis en que el proceso aún no ha terminado por sentencia firme. De esta manera, la pregunta que nace es la siguiente: ¿Es posible durante el transcurso del proceso atacar los vicios que padece la actividad procesal a través de la nulidad de derecho público? Nuestra respuesta también es negativa. En efecto, durante el correr del procedimiento los posibles vicios que adolece la actividad procesal, en caso que a petición de parte no se denuncien o que el juez de oficio no los perciba, por regla general, serán purgados por las diferentes especies de convalidación, salvo que se trate de un vicio de carácter insubsanable.

De un modo general, la convalidación constituye una técnica a través de la cual un acto que en principio es inválido, por diversas causas que dispone el ordenamiento jurídico, pasa a ser considerado válido, sin necesidad de corregir el defecto ${ }^{50}$.

perseguir sanciones por vicios ocurridos durante la tramitación y que no fueron reclamados en la forma requerida por la ley, toda vez que en tales condiciones, la falta debe considerarse convalidada, cuando el efecto jurídico de cosa juzgada ampara al fallo de la causa".

50 En cuanto a su naturaleza, se ha señalado que la convalidación constituye una renuncia. Así lo afirma OTERo (2000) p. 96, al afirmar que "la convalidación es en sí una renuncia al derecho de impetrar la nulidad de un acto jurídico procesal que afecta a la parte. Esto es reconocer tácita o expresamente la existencia de tal acto jurídico procesal y de sus efectos propios, sin reclamar de los vicios de que pueda adolecer y que pueden originar su nulidad". En sentido similar se pronuncia MAURINo (2001) p. 62, al expresar que: "la convalidación o confirmación es la renuncia de la parte a pedir la nulidad del acto que de esta manera se subsana”. En idéntico sentido CоLомво (1997) t. II, p. 478. Explicar la convalidación según la teoría de la renuncia creemos que no es del todo acertado, pues, la renuncia impide volver a plantear la cuestión nuevamente. Esto funciona respecto de todos los vicios que pueden ser denunciados por las partes, pero no respecto de aquellos que pueden ser apre- 
La convalidación del vicio que padece un acto procesal constituye otro límite que impide obtener la declaración judicial de nulidad procesal. Esta técnica que obsta la declaración de ineficacia puede estar motivada por diversas razones ${ }^{51}$. Así, por ejemplo, la convalidación impide que actúe la declaración de nulidad porque el defecto o irregularidad es irrelevante (mera irregularidad, defecto intrascendente), porque la parte legitimada para pedir la nulidad decide no hacerlo manifestando su voluntad en forma expresa o tácita (convalidación expresa y tácita), porque el acto alcanzó la finalidad a la cual estaba destinado (cumplimiento de la finalidad), bien porque ha precluido la oportunidad procesal para denunciarlo (convalidación por preclusión) o, finalmente, porque el proceso ya ha concluido en forma definitiva en virtud de la cosa juzgada (convalidación por cosa juzgada) ${ }^{52}$. En el evento que actúe alguna de estas formas o especies de convalidación, los vicios que sufrió la actividad procesal ya no podrán ser denunciados posteriormente porque actuó la convalidación, es decir, el acto se validó y ya no será susceptible de ser invalidado.

En otras palabras, las eventuales convalidaciones constituyen un límite que impide declarar la nulidad de un acto, es decir, son verdaderas normas que clausuran la posibilidad de impugnar posteriormente los posibles defectos que pueda adolecer la actividad procesal, los que, lógicamente, obstruye impugnar la eficacia de los mismos una vez que actuaron los límites referidos. A este argumento se suma el referido al principio de legalidad, bajo el cual, los actos procesales deben ser atacados por los instrumentos que el Derecho procesal dispone para tales fines y no por otras instituciones, categorías o mecanismos pertenecientes a otras ramas del Derecho, de las cuales el Derecho procesal es autónomo.

De aceptarse que la nulidad procesal de derecho público fuese aplicable a los actos jurisdiccionales se estarían conculcando los límites que impiden declarar la nulidad, límites que la ley expresamente reconoce, desnaturalizándose el sistema anulatorio y no surtiendo efecto las eventuales convalidaciones que han operado o actuado durante el transcurso del procedimiento.

Por otra parte, preguntamos a quienes propenden que in limine litis un acto procesal viciado es posible de invalidarse en virtud de la nulidad procesal de derecho público: ¿cuál es la diferencia entre aplicar la nulidad procesal y la nulidad procesal de derecho público?, ¿se trata de dos mecanismos de invalidación autónomos?, ¿en el evento de perder el inci-

ciados por el juez en cualquier momento del proceso. En este último caso, aunque las partes hayan convalidado expresa o tácitamente el vicio o haya actuado la convalidación por preclusión, si se trata de un vicio que de lugar al recurso de casación o que infrinja el orden público procesal, el juez igualmente podrá declarar la nulidad procesal. Consideramos que la naturaleza de la convalidación debiera explicarse por el principio de preclusión, ya sea en su fase de extinción de una carga procesal o de consumación del acto, cuyo efecto es la convalidación de las irregularidades ocurridas durante el juicio.

51 SALAS (2004) pp. 89-97, distingue diversas maneras en que puede actuar la convalidación, las que en síntesis se resumen en las siguientes: a) Dependiendo del momento en que se produce la convalidación, se diferencia la convalidación anticipada de la definitiva; b) Dependiendo de la manifestación de voluntad en relación con la conformidad de la parte que puede alegar la nulidad, se diferencia la convalidación expresa de la tácita; c) Dependiendo del sujeto procesal que puede convalidar, se diferencia la convalidación del acto nulo y la rectificación del acto nulo.

52 La subsanación se diferencia de la convalidación en que aquella tuvo por objeto la eliminación o enmienda del vicio que afectaba al acto, el cual, una vez corregido o subsanado, hace contraproducente que actúe la nulidad procesal. 
dente de nulidad procesal o el recurso de casación en la forma entonces aún queda vigente la posibilidad de deducir posteriormente un incidente de nulidad procesal de derecho público?, ¿qué sentido tiene que la ley exija la preparación del recurso de casación en la forma si posteriormente podría igualmente deducir una nulidad de derecho público para corregir el mismo vicio?, ¿cómo explicaríamos que a través de la aplicación de la nulidad de derecho público pasan a ser inútiles todos los mecanismos procesales de convalidación de los vicios que puede adolecer la actividad procesal?.

Recuérdese que la nulidad de derecho público suele caracterizarse que es imprescriptible, insubsanable, no convalidable y actúa de pleno derecho; en cambio, la nulidad procesal por regla general precluye, es subsanable, es convalidable y necesita ser declarada judicialmente.

Estos problemas no son expuestos ni resueltos por quienes afirman la aplicación de la nulidad de derecho público contra los actos jurisdiccionales viciados, lo que demuestra confusión en la aplicación de dicho estatuto a la actividad jurisdiccional irregular.

\section{LA NULIDAD PROCESAL DE DERECHO PÚBLICO, EN EL EVENTO QUE FUESE APLICABLE A LOS ACTOS JURISDICCIONALES, NO PODRÍA OPERAR IPSO IURE}

La doctrina no está conteste en afirmar que la nulidad de derecho público opera ipso iure $^{53}$. Más de acuerdo está en asignar los caracteres de ser insanable $e^{54}$ e imprescriptible $e^{55}$. Estas mismas características se afirman para la nulidad procesal de derecho público, aunque existen posiciones en contrario. Estas características que afirma la doctrina hacen imposible sostener la aplicación de la nulidad procesal de derecho público a los actos procesales o al proceso, por las razones que desarrollaremos a continuación.

Nuestro actual sistema de enjuiciamiento civil no reconoce la aplicación de una nulidad procesal de pleno derecho ${ }^{56}$, pues, las causales específicas o genéricas de nulidad procesal, contenidas en el Código de Procedimiento Civil, para que actúen, necesitan ser declaradas judicialmente. En efecto, la opinión mayoritaria de la doctrina y la jurisprudencia es que la nulidad procesal, para que actúe, necesita ser declarada judicialmente ${ }^{57}$. Entonces,

\footnotetext{
53 En el sentido que la nulidad de derecho público opera ipso iure se manifiestan, entre otros, SoTо (2009) pp. 433-435; Fiamma (1986) pp. 123-128; Fiamma (1991) p. 97; Silva (1997) t. IV, pp. 158 y ss.; MarTíneZ (2003) p. 8. En contra de esta postura y abogando por la necesaria declaración judicial se pronuncian SILVA (2001) p. 143 y ss.; ReYes (2000) p. 20-42; Reyes (2002) pp. 99 y ss.; PfeFfer (2005) p. 138.

54 Soto (2009) p. 433; Fiamma (1991) p. 97; Martínez (2003) p. 8.

55 En este sentido se pronuncian Soto (2009) p. 433; Fiamma (1986) pp. 123-128; Fiamma (1991) p. 97.

56 En contra de nuestra afirmación cfr. TAVOLARI (2000) pp. 266-270, quien, sin perjuicio de reconocer que para que actúe la nulidad procesal debe ser declarada judicialmente, explica varias hipótesis de nulidades procesales que actúan de pleno derecho como, por ejemplo, entre otros, en la declaración de incompetencia del juez por inhibitoria, en la declaración de una implicancia, en la declaración de abandono del procedimiento, en el evento que se conceda el recurso de apelación en el solo efecto devolutivo, en las medidas prejudiciales precautorias y precautorias.

57 Cfr., por todos Salas (2004) pp. 75 y ss.; Colombo (1997) t. II, pp. 469 y ss. La necesidad que la nulidad sea declarada judicialmente para que produzca sus efectos se desprende de diversas normas del Código de Procedimiento Civil. Así, el artículo 83 del CPC, tanto sus incisos $1^{\circ}$ y $3^{\circ}$ aluden a la declaración de nulidad.
} 
afirmar que la nulidad procesal de derecho público aplicable a la actividad procesal, opera ipso iure, significa contrariar el espíritu de todo el sistema procesal anulatorio y las propias disposiciones ${ }^{58}$ sobre nulidad.

Hay que tener en consideración que la declaración de nulidad procesal es necesaria porque mientras el juez no dicte una resolución judicial que contenga esa declaración, los efectos del acto eventual o potencialmente nulo siguen desplegándose en el proceso.

El argumento contenido en el párrafo anterior permite comprender que quienes aseveran que la nulidad de derecho público es aplicable de pleno derecho a los actos jurisdiccionales parten de una base histórica errada y, además, tal afirmación genera un estado de incertidumbre jurídica que el legislador quiere evitar, como analizaremos inmediatamente.

Como aludimos, una parte de la doctrina suele sostener que la nulidad de derecho público opera de pleno derecho y argumenta, en síntesis nuestra, que esto se produce porque la Constitución supone el sometimiento del poder al Derecho, lo que entre otras cosas se logra mediante las normas de creación de órganos del Estado y de asignación de competencias que aquella contiene. En otras palabras, la actuación de los órganos del poder debe sujetarse a estas; más aún, estos solo pueden hacer aquello que expresamente les autoriza o encomienda la Constitución. En caso contrario, sus actuaciones no nacen a la vida del Derecho, no serán Derecho, serán nulas y sin ningún valor. Ello porque los actos de dichos órganos solo pueden nacer si se cumplen los preceptos contenidos en la Constitución y en las normas legales y reglamentarias que los regulan. Es decir, el efecto que produce la contravención de las normas contenidas en la Constitución, es la nulidad del acto así generado, el que no tendrá ningún efecto jurídico ${ }^{59}$.

Por otro lado, si entendemos que la nulidad de derecho público equivale a inexistencia $^{60}$, ello produce una serie de inconsistencias en materia procesal -en caso que se quiera aplicar este tipo de nulidad a la actividad procesal- porque las resoluciones judiciales no pueden ser desconocidas o desobedecidas, pues, los tribunales de justicia son independientes y sus decisiones tienen imperio, por lo que la nulidad de las resoluciones judiciales o del proceso mismo debe impetrarse durante el curso del procedimiento (in limine litis) a través de los mecanismos que el Derecho procesal considera aptos para tal fin. De aplicarse la nulidad de derecho público a las resoluciones que pronuncian los tribunales equivaldría a afirmar que estas son inexistentes, que son la nada, que no producen efecto, conclusiones

\footnotetext{
58 Contraría las disposiciones del CPC y el espíritu de la Ley $\mathrm{N}^{\circ} 18.705$, pues, de varias normas se desprende textualmente que la nulidad necesita de declaración judicial como lo son los artículos 83 incisos $1^{\circ}$ y $3^{\circ} \mathrm{CPC}$.

59 Lo que explicamos es una síntesis de las ideas expresadas por Soто (2009) pp. 433 y ss.; Sото (1991-1992) pp. 420-426.

60 Así lo afirman Sото (2009) p. 460, donde expresa: "Que sea nulo significa que no es acto, pues eso es lo que dispone el artículo $7^{\circ}$ inciso $3^{\circ}$ en su frase primera. Y si no es acto, quiere decir pura y simplemente que no existe acto, y si no es acto ni existe como tal, quiere decir que es inexistente; de allí que la nulidad que consagra la Constitución como efecto de la contravención a ella en que se incurra en la dictación de los actos de los órganos estatales se diga que es 'inexistencia”. En el mismo sentido cfr. BoCKSANG (2006) pp. 109, afirma que: “... el reconocimiento de la nulidad de derecho público como inexistencia no es para nada una creación ex nibilo, proveniente de la imaginación delirante de un grupo de catedráticos, sino que, por el contrario, con el derecho romano como origen remoto, fue recogida y enarbolada entre los estardartes de la Independencia, hasta consolidarse, conjuntamente con el orden institucional de la República, en la Constitución de 1833”.
} 
que son totalmente contrarias al sistema de enjuiciamiento en donde las resoluciones judiciales producen sus efectos una vez que se notifican válidamente con arreglo a la ley (art. 38 $\mathrm{CPC}$ ), efectos que se despliegan en el tiempo, al menos hasta que otra resolución judicial las anule, eliminándose, de esa manera, los efectos de la resolución viciada.

Partir de la base que un acto nulo no produce ningún valor o efecto es errado y se confunden los términos invalidez e ineficacia. En efecto, tal conclusión se produce por una transposición del viejo aforismo quod nullum est nullum producit effectum el cual genera una serie de equívocos que lo hacen rechazable. Como explica Santamaría Pastor -refiriéndose a la nulidad de pleno derecho-, las construcciones parten de premisas falsas, pues, "en la realidad jurídica, la nulidad no se produce nunca de modo automático, porque la nulidad no es un hecho, una realidad, sino una calificación que debe hacerse valer en el procedimiento correspondiente para que sea efectiva" ${ }^{61}$.

El adagio quod nullum est nullum producit effectum tantas veces citado por la doctrina no quiere decir que lo que es nulo ningún efecto produce. Con claridad lo explica Díez-Picazo: "la idea de nullum effectum, no expresa una apariencia o un fenómeno real, sino un mandamiento o una sanción de orden jurídico. Quiere decirse que, a pesar de estar sancionado el nullum effectum, puede producirse o haberse producido en virtud del negocio ineficaz una mutación en la realidad social idéntica a la que ocasionaría un negocio eficaz. (...) Por ello, acaso más exacto que decir que el contrato es ineficaz y que no produce ningún efecto, fuera decir que el contrato debe ser tenido como ineficaz y que no debe producir ningún efecto. La ineficacia jurídica es una fórmula que encierra una disciplina normativa y que por consiguiente, pertenece al mundo del deber ser: quod nullum est nullum effectum producere debet" 62 .

Refiriéndose a este adagio, Lutzesco afirma que "debe cambiarse su fundamento: no puede estar ya vinculado a la nulidad misma, sino a la acción de nulidad, por la sencilla razón de que actualmente el acto nulo produce los mismos efectos que el acto válido, en tanto no se haya pronunciado una decisión judicial. Haciéndolo pasar al campo de la acción conservará parte de su antigua majestad, para expresar los efectos de la acción de nulidad"63.

Del postulado errado que hemos explicado resulta casi innegable decir-como afirma la doctrina que sustenta que la nulidad equivale a inexistencia- que la nulidad se produce $a b$ initio y que no necesita de declaración judicial pues, el acto nulo lo es antes y con independencia de cualquier intervención judicial. Desde esta premisa se deduce que, si el acto es nulo desde un principio, entonces, no es posible sanarlo y que lo que es nulo desde un comienzo no puede validarse por el transcurso del tiempo, sosteniéndose en definitiva la imprescriptibilidad de la acción de nulidad de derecho público.

Como explicamos, la doctrina procesal mayoritaria sostiene que la nulidad procesal de los actos jurisdiccionales necesita de declaración judicial y, mientras esto no ocurra, los actos ejecutados y el proceso mismo (en su conjunto) generan todos los efectos que la ley les atribuye. Ahora, quienes expresan que la nulidad de derecho público opera ipso iure respecto de todos los actos de los órganos del Estado que sean contrarios al principio de

\footnotetext{
61 Santamaría (1975) p. 93.

62 Díez-Picazo (2007) vol. I, p. 571.

63 Lutzesco (1945) p. 270.
} 
juridicidad, ello es impracticable especialmente respecto de los actos jurisdiccionales. Reiterando que somos de la opinión que esta teoría es inaplicable a los actos jurisdiccionales, en el evento que quisiéramos sostener lo contrario, no es posible afirmar que esta actúe de pleno derecho. En efecto, los actos procesales potencialmente nulos generan todos los efectos que la ley les atribuye mientras no sean declarados ineficaces, por lo cual, sostener que la nulidad procesal de derecho público actúa ipso iure es desconocer todo el sistema anulatorio procesal el cual se basa en la posibilidad de convalidación del vicio y en el efecto de cosa juzgada que adquieren las sentencias interlocutorias y definitivas firmes ${ }^{64}$.

Por otra parte, consideramos que es infundado afirmar que en virtud de un cambio de normas, como es aplicar al caso concreto - al acto procesal o al proceso en su conjuntola nulidad procesal de derecho público, pueda sostenerse ahora que el acto es nulo desde un principio, que no produjo efecto y, finalmente, que no requiere declaración judicial, pues, se produce una contradicción entre lo que la teoría pretende explicar y lo que realmente ocurre en la práctica.

\section{LA NULIDAD DE DERECHO PÚBLICO DESCONOCE FLAGRANTEMENTE EL PRINCIPIO DE TRASCENDENCIA DEL PERJUICIO QUE EXIGE LA NULIDAD PROCESAL}

Quienes aseveran la aplicación de la nulidad de derecho público a los actos jurisdiccionales desconocen flagrantemente el principio de trascendencia del perjuicio que se exige para declarar la nulidad procesal.

La nulidad procesal de derecho público desconoce el funcionamiento y aplicación del estatuto anulatorio tradicional contenido en el Código de Procedimiento Civil. En efecto, como se sabe, para que actúe la nulidad procesal debe existir un vicio que irrogue un perjuicio para alguno de los litigantes solo reparable con la declaración de ineficacia; es lo que denominamos como el principio de trascendencia del vicio que afecta al acto. Para la doctrina clásica de la nulidad de derecho público, basta una mera contravención de los requisitos del acto para declararlo nulo de pleno derecho. Ellos, al interpretar el término contravención, afirman que "ha de advertirse que no cabe sostener, bajo el amparo de la Constitución, que los vicios que se cometan en el procedimiento de elaboración de un acto, de un órgano estatal, solo invalidan el acto en cuanto fueran 'gruesos' o 'groseros', como a veces se lee o escucha, porque bajo tal subterfugio o falacia se viola flagrantemente la Constitución, la cual no hace distinción alguna al respecto ni podría hacerla tampoco, ya que con ella se hace tabla

${ }^{64}$ Esto también es aplicable a materia administrativa en virtud del artículo 9 de la Ley $\mathrm{N}^{\circ} 19.980$. Así lo ha declarado una sentencia de la CS. 24 de septiembre de 2010, Rol N 1082-2010 (Cita LegalPublishing: CL/ JUR/7673/2010; 45800), al sostener: "Que la nulidad del derecho público, constituye una sanción de ineficacia jurídica que afecta a aquellos actos de los órganos del Estado en los que faltan algunos de los requisitos que el ordenamiento establece para su existencia y validez. Dicho instituto se rige por principios como el de la trascendencia y de la conservación, conforme a los cuales el vicio de procedimiento o de forma solo afecta la validez del acto administrativo cuando recae en algún requisito esencial del mismo, sea por naturaleza o por mandato del ordenamiento jurídico y genera perjuicio al interesado (artículo 9 Ley 19.880). En efecto, dada la trascendencia de la acción administrativa, la nulidad toma el carácter de un remedio excepcional frente a la ilegalidad, operando solo si la falta es de real entidad" (el destacado es nuestro). 
rasa de la Carta Fundamental dejándose entregado al arbitrio del autor nada menos que una garantía básica, primordial, como lo es el 'debido procedimiento', que ampara y protege un 'derecho fundamental'" ${ }^{65}$. A esto debe sumarse lo expresado por Otero Lathrop quien afirma -en síntesis nuestra- que si se está en presencia de un acto procesal afectado por la nulidad procesal de derecho público el tribunal debe declararla de oficio sin que exista forma alguna de saneamiento y aun cuando no exista perjuicio alguno para las partes ${ }^{66}$.

Analicemos esto desde la perspectiva procesal. La nulidad procesal existe desde antaño, pero a medida que la institución ha evolucionado, se han incorporado una serie de principios que la informan e inspiran. Entonces, si hacemos un recuento histórico de esta evolución nos preguntamos lo siguiente en relación con el principio de trascendencia del perjuicio:

¿Para qué hemos tenido dos grandes reformas a nuestro Código de Procedimiento Civil, la primera producida por la Ley $N^{\circ} 7.760$ de 1944 y la segunda generada por la Ley $\mathrm{N}^{\circ}$ 18.705, de 1988, que incorporaron, la primera de estas, la noción de perjuicio al recurso de casación en la forma y la potestad anulatoria de oficio y, la segunda, que introdujo una serie de límites externos que impiden la declaración de nulidad procesal, si con la nulidad de derecho público o la nulidad procesal de derecho público todos estos logros y adelantos legislativos serian infructuosos?

La exigencia que alguna de las partes sufra un perjuicio trascendente pretendió morigerar aquellas interpretaciones formalista o ritualistas en las que se declaraba la nulidad del acto independiente de la irregularidad cometida. En efecto, actualmente no tiene sentido anular un acto defectuoso si el vicio de que adolece es incapaz de generar un perjuicio trascendente o importante para la parte que alega la nulidad. En caso de aplicarse la nulidad de derecho público al acto jurisdiccional tal como lo explica la doctrina clásica, esto es, que ella es procedente para impugnar cualquier vicio, sea que este sea grosero o nimio, desconoce el notable adelanto que importó la incorporación de la trascendencia del vicio a nuestro sistema anulatorio, volviendo a una interpretación formalista tan repudiada por el Derecho procesal.

\section{LA APLICACIÓN DE LA NULIDAD PROCESAL DE DERECHO PÚBLICO A LOS ACTOS JURISDICCIONALES SOBREPASA EL RÉGIMEN DE IMPUGNACIÓN DE LA ACTIVIDAD PROCESAL IRREGULAR REGULADO EN EL CÓDIGO DE PROCEDIMIENTO CIVIL}

Para explicar el título de este apartado nos preguntamos lo siguiente: ¿cuáles serían las razones para querer sobrepasar el sistema anulatorio contemplado en el Código de Procedimiento Civil? ¿Acaso no basta con las excepciones dilatorias, los incidentes de nulidad procesal, la nulidad incidental de oficio, la solicitud de reposición, el recurso de apelación, el recurso de casación en la forma, la casación en la forma de oficio, todos los cuales están destinados directa o indirectamente a evitar las nulidades, subsanar los posibles vicios, corregir los errores de procedimiento, observar los presupuestos procesales, corregir los errores de incongruencia de la sentencia, etc.?

65 Soto (2009) p. 457.

66 Otero (2009) p. 268. 
Consideramos que la nulidad procesal de derecho público no puede sobrepasar el sistema anulatorio de los actos procesales defectuosos contenido en el Código de Procedimiento Civil. En efecto, aunque se diga que la nulidad procesal de derecho público tiene un origen constitucional y que, por tanto, ella está por encima del sistema anulatorio que rige la actividad procesal civil, tal forma de interpretación desconoce la especialidad de las reglas contenidas en el Código de Procedimiento Civil, vulnera el criterio de interpretación sistemática de la ley y pugna contra los límites legales que impiden declarar la nulidad procesal.

Para explicar lo anterior, nos preguntamos ¡cuáles son los límites de la nulidad de derecho público en relación con los mecanismos procesales de impugnación de las resoluciones judiciales? Como se ha dicho, la doctrina tradicional asevera que la aplicación de la nulidad procesal de derecho público al acto jurisdiccional se puede impetrar tanto durante el procedimiento como una vez que este ha finalizado. Entonces, durante el procedimiento, ¿cuáles son los límites para determinar cuándo se aplica la casación y cuándo la nulidad procesal de derecho público?, ¿cuál es el límite o criterio que determina aplicar los mecanismos procesales contenidos en el Código de Procedimiento Civil o el estatuto de la nulidad procesal de derecho público que se extrae de las normas contenidas en la Constitución?

Ahora, una vez que el proceso concluye por sentencia firme, como se sabe, la acción de revisión es el único medio procesal que el legislador reguló con el objeto de rever una sentencia firme y cuyas causales que actualmente están contenidas en el artículo 810 CPC se remontan a la Ley Mariana sobre recurso de nulidad, de 1 de marzo de 1837. ¿Acaso la nulidad de derecho público puede traspasar esta barrera y atacar la cosa juzgada por cualquier contravención a la Constitución o la ley? Llevando esto al extremo, ¿acaso después de cincuenta o cien años desde que una sentencia definitiva o interlocutoria quedó firme, podemos dejarla sin efecto a través de la acción de nulidad de derecho público? ¿Dónde queda la seguridad jurídica que debe asignarse a toda resolución pronunciada por los tribunales de justicia una vez que logra el estado de firmeza o ejecutoriedad?

\section{CONCLUSIONES}

En nuestra opinión, todos estos argumentos que hemos descrito precedentemente hacen comprender que la doctrina clásica de la nulidad de derecho público debe replantear sus postulados, especialmente en lo que dice relación con su procedencia contra los actos jurisdiccionales, pues, aquella no ha logrado explicarla satisfactoriamente en relación con el estatuto anulatorio aplicable a la actividad procesal defectuosa o viciada contenida en el Código de Procedimiento Civil.

En consecuencia, el estatuto de la nulidad de derecho público o, en su derivación más moderna, la nulidad procesal de derecho público, es improcedente aplicarlo contra los actos jurisdiccionales porque:

1. Quebranta el ámbito de aplicación de la nulidad procesal de derecho público;

2. No distingue que la actividad jurisdiccional sea de auctoritas y no de potestas;

3. Infringe el principio de legalidad;

4. Atenta contra la historia fidedigna del establecimiento del Código de Procedimiento Civil; 
5. Vulnera el fin y razón de ser de la cosa juzgada;

6. Transgrede los límites del sistema anulatorio procesal civil que impiden declarar la nulidad;

7. La nulidad de derecho público, en el evento que fuese aplicable a los actos jurisdiccionales no podría operar ipso iure;

8. Desconoce flagrantemente el principio de trascendencia del perjuicio que exige la nulidad procesal; $y$

9. Sobrepasa el régimen de impugnación de la actividad procesal irregular regulado en el Código de Procedimiento Civil.

\section{BIBLIOGRAFÍA CITADA}

Barrios de Ángelis, Dante (1979): Teoría del proceso (Aires Buenos, Depalma).

Bernaschina GonzÁlez, Mario (1950): "Bases jurisprudenciales para una teoría de las nulidades administrativas", en Boletín de la Contraloría General de la República, 1950, t. II: pp. 401-412.

Bernaschina González, Mario (1958): Manual de derecho constitucional (Santiago, Editorial Jurídica de Chile, tercera edición, t. I).

Bocksang Hola, Gabriel (2006): "De la nulidad de derecho público como inexistencia”, Ius Publicum, Escuela de Derecho, Universidad Santo Tomás, No 16: pp. 91-116.

Bocksang Hola, Gabriel (2013): "El ámbito de aplicación de la nulidad de derecho público" en Ferrada Bórquez, Juan Carlos (dir.), La nulidad de los actos administrativos en el derecho chileno (Santiago, LegalPublishing/Thomson Reuters) pp. 49-75.

Calamandrei, Piero (1973): Derecho procesal civil. Estudios sobre el proceso civil (traducción de Santiago Sentís Melendo), edit. E.J.E.A., Buenos Aires, t. III).

Chiovenda, Giuseppe (1977): Principios de derecho procesal civil (traducción de la $3^{a}$ edición italiana por José Casais y Santaló, Madrid, Instituto Editorial Reus, t. II).

Concha Machuca, Ricardo (2013), "El desarrollo del régimen jurídico de la nulidad de derecho público", Revista de Derecho, Universidad Austral, vol. XXVI, No 2: pp. 93-114.

Colombo Campbell, Juan (1968): La jurisdicción en el derecho chileno (Santiago, Editorial Jurídica de Chile).

Colombo Campbell, Juan (1997): Los actos procesales (Santiago, Editorial Jurídica de Chile, t. II).

Couture, Eduardo (2011): Fundamentos del derecho procesal civil (Buenos Aires, Editorial B y F, cuarta edición).

D’Ors, Álvaro (2004): Derecho privado romano (Eunsa, Pamplona, décima edición).

Díez-Picazo, Luis (2007): Fundamentos del derecho patrimonial (Pamplona, Editorial Thomson-Civitas, sexta edición, vol. I).

Domingo, Rafael (1999): Auctoritas (Barcelona, Ariel S.A.)

Fiamma Olivares, Gustavo (1986): "La acción constitucional de nulidad: un supremo aporte del constituyente de 1980 al Derecho Procesal Administrativo", Revista de Derecho y Jurisprudencia, t. LXXXIII, No 3: pp. 123-128.

Fiamma Olivares, Gustavo (1991): "La acción constitucional de nulidad y legitimación activa objetiva”, Revista de Derecho Público, No 49: pp. 91-98. 
Galté Carré, Jaime (1954): Manual de organización y atribuciones de los tribunales (Santiago, Editorial Jurídica de Chile).

Gutiérrez de Cabiedes, Eduardo (1974): Estudios de derecho procesal (Pamplona, Ediciones Universidad de Navarra S.A.).

Hernández Galilea, Jesús Miguel (1995): La nueva regulación de la nulidad procesal (Oviedo, Editorial Forum).

Hoyos Henrechson, Francisco (2001): Temas fundamentales de derecho procesal (Santiago, Editorial ConoSur/LexisNexis).

Huneeus Jorge (1890): La Constitución ante el Congreso (Santiago, Editorial Imprenta Cervantes, segunda edición).

Jara Miranda, Eduardo (1950): Nulidad de derecho público (Santiago, Editorial Universitaria).

JARA SCHNETTLER, Jaime (2004): La nulidad de derecho público ante la doctrina y la jurisprudencia (Santiago, Libromar).

López Pescio, Edgardo (1987): Nociones generales de derecho procesal (Valparaíso, Editorial Edeval, t. I).

Lorca Navarrete, Antonio María (1993): Organización judicial española y principios rectores del proceso español (Madrid, Dykinson).

Lozano-Higuero Pinto, Manuel (1990), Introducción al derecho procesal (Madrid, Editorial Ministerio de Justicia).

LutzesCo, Georges (1945): Teoría y práctica de las nulidades (traducción de Manuel Romero Sánchez y Julio López de la Cerda), (México, Editorial Porrúa).

Marín Vallejo, Urbano (2004): "Algunos aspectos de la nulidad de derecho público. Aproximación práctica al tema”, en Onfray Vivanco, Arturo (director) Seminarios de derecho procesal. Reforma orgánica al proceso civil. La defensa del Estado ante los Tribunales de Justicia: Una aproximación particular a la nulidad de derecho público (Cuadernos de Análisis Jurídico, Escuela de Derecho, Universidad Diego Portales, Serie Publicaciones Especiales, No 17) pp. 143-156.

Martínez Estay, José Ignacio (2003): Algunas reflexiones sobre la nulidad de derecho público, Documento de Trabajo $N^{\circ}$ 56, Universidad de los Andes, Facultad de Derecho (inédito)

MaUrino, Luis Alberto (2001): Nulidades procesales (Aires Buenos, Editorial Astrea, segunda edición).

Montero Aroca, Juan et al (2011): Derecho jurisdiccional, t. II (Valencia, Editorial Tirant lo Blanch, decimonovena edición).

Morón Palomino, Manuel (1957): La nulidad en el proceso civil español (Barcelona, Editorial AHR).

Muñoz DíAz, Patricio (2001): Informe Constitucional, Informe No 2.495, de 25 de junio de 2001.

Nieva Fenoll, Jordi (2006): Cosa juzgada (Barcelona, Editorial Atelier).

Oberg Yáñez, Héctor, Manso Villalón, Macarena (2008): Derecho procesal orgánico (Santiago, LexisNexis).

Ortúzar Latapiat, Waldo (2000): Informe Constitucional, Informe No 2.317, de 25 de septiembre de 2000.

Otero Lathrop, Miguel (2000): Derecho procesal civil. Modificaciones a la legislación 19882000 (Santiago, Editorial Jurídica de Chile). 
Otero Lathrop, Miguel (2009): La nulidad procesal civil, penal y de derecho público (Santiago, Editorial Jurídica de Chile).

Pereira Anabalón, Hugo (1954): La cosa juzgada formal en el procedimiento civil chileno (Santiago, Editorial Jurídica de Chile).

Pereira Menaut, Antonio-Carlos (2006): Teoría constitucional (LexisNexis, Santiago, segunda edición).

Pfeffer Urquiaga, Emilio (2005): "La nulidad de derecho público, tendencias jurisprudenciales", Revista de Derecho Público, Universidad de Chile, 2005, vol. 67: pp. 129-144.

Poblete Vinaixa, Julia (2013): "El carácter prescriptible o imprescriptible de la acción de nulidad de derecho público" en Ferrada Bórquez, Juan Carlos (dir.) La nulidad de los actos administrativos en el derecho chileno (Santiago, LegalPublishing/Thomson Reuters) pp. 335-359.

Proyecto de Código de Enjuiciamiento Civil, edit. El Progreso, Santiago, 1884.

Reyes Riveros, Jorge (2000): La nulidad de derecho público (LexisNexis, Santiago).

ReYes Riveros, Jorge (2002): Invalidación de actos administrativos (Santiago, Editorial LexisNexis).

Romero Seguel, Alejandro (2001): "El control de oficio de los presupuestos procesales y la cosa juzgada aparente. La capacidad procesal”, Revista Chilena de Derecho, vol. 28, No 4, pp. 781-789.

Romero Seguel, Alejandro (2003): "La improcedencia de la acción de nulidad de derecho público para revisar resoluciones judiciales como precedente judicial” en Revista Chilena de Derecho, vol. 30, N², pp. 381-385.

Romero Seguel, Alejandro (2003): La cosa juzgada en el proceso civil chileno (Santiago, Editorial Jurídica de Chile).

Salas Vivaldi, Julio (2004): Los incidentes y en especial el de nulidad en el proceso civil, penal y laboral (Santiago, Editorial Jurídica de Chile, séptima edición).

Santa Cruz Serrano, Víctor (1936): Ensayo sobre la teoría de las nulidades procesales en el código de procedimiento civil chileno (Santiago, Editorial Imprenta Chile).

Santamaría Pastor, Juan (1975): La nulidad de pleno derecho en los actos administrativos (Contribución a una teoría de la ineficacia en el derecho público), (Madrid, Editorial Instituto de Estudios Administrativos).

Silva Bascuñán, Alejandro (1997): Tratado de derecho constitucional (Santiago, Editorial Jurídica de Chile, segunda edición).

Silva Cimma, Enrique (2001): Derecho Administrativo chileno y comparado. Actos y contratos administrativos y bienes públicos (Santiago, Editorial Jurídica de Chile).

Soto Kloss, Eduardo (1991-1992): "La nulidad de derecho público referida a los actos de la administración”, Revista de Derecho, Universidad Católica de Valparaíso, vol. XIV: pp. 417-431.

Sото KLoss, Eduardo (2009): “La nulidad de derecho público en el derecho chileno", en Derecho administrativo. Temas fundamentales (Santiago, LegalPublishing/AbeledoPerrot) pp. 427-453.

Tapia Fernández, Isabel (2000): El objeto del proceso. Alegaciones. Sentencia. Cosa juzgada (Madrid, Editorial La Ley). 
Tavolari Oliveros, Raúl (2000): "La nulidad procesal en el derecho actual", en El proceso en acción (Santiago, Editorial Libromar Ltda.) pp. 241-278.

Vergé Grau, Joan (1987): La nulidad de actuaciones (Barcelona, Editorial Librería Bosch).

\section{JURISPRUDENCIA CITADA}

Servicio Nacional de Geología y Minería contra Sociedad Química y Minera de Chile S.A (2010): Corte Suprema, 24 de septiembre de 2010, Rol No 1082-2010, Cita LegalPublishing: CL/JUR/7673/2010.

Corte de Apelaciones de Valdivia, 2 de septiembre de 2009, Rol No 304-2009 (Cita Legal Publishing: CLJUR/793/2009; J55.491/2009).

Junta de Vigilancia de la Última Sección del Río Mapocho y otros con Superintendencia de Servicios Sanitarios (2008): Corte Suprema, 22 de diciembre de 2008, Rol No 9556-2004, Cita LegalPublishing CL/JUR/6153/2008.

Roberto Hagemann Gerstmann y otro con Comunidad Agricola Totoral (2008): Corte de Apelaciones de Copiapó, 17 de junio de 2008 (acción de nulidad absoluta y nulidad de derecho público), Rol No 272-2007, CL/JUR/5401/2008.

Corte Suprema, 22 de octubre de 2002, FM, No 503, sentencia No 11, pp. 3086 y ss.

(2002): de Chillán, 3 de abril de 2002, Rol No 198.561-2002

(2002): Corte de Apelaciones de Santiago, 19 de marzo de 2002, Revista de Derecho y Jurisprudencia, t. IC, sec. $2^{\text {a }}$, pp. 20-21.

Pedro Aburto Abril contra Sociedad Machasa SA (2001): Corte Suprema, 10 de julio de 2001, Rol No 337-1998, Cita LegalPublishing CL/JUR/260/2001.

Municipalidad de San Fernando c. Espinoza Figueroa y otros (2000): Corte Suprema, 29 de agosto de 2000, Rol No 3408-1998, Cita LegalPublishing CL/JUR/452/2000.

(1993): Corte de Apelaciones de Punta Arenas, 28 de mayo de 1993, Revista de Derecho y Jurisprudencia, t. XC, sec. 2", pp. 74-76.

Corte de Apelaciones de Antofagasta, 15 enero 1993. Revista de Derecho y Jurisprudencia, t. XC, sec. 2", pp. 9-11

Corte Suprema, 4 mayo 1990, Revista de Derecho y Jurisprudencia., t. LXXXVII, sec. 1'a, pp. 21-30.

Corte Suprema, 26 diciembre 1989, Revista de Derecho y Jurisprudencia, t. LXXXVI, sec. 1'a, pp. 151 y ss.

Corte Suprema, 2 de mayo de 1988, Revista de Derecho y Jurisprudencia, t. LXXXV, sec. 1a, pp. 67 y ss. (también en FM., No 354, pp. 248 y ss.)

Corte Suprema, 25 de octubre de 1963, Revista de Derecho y Jurisprudencia, t. LX, sec. 1a, pp. 316 y ss. (también en FM., No 59, octubre, 1963, pp. 216-217).

Corte Suprema, 9 de mayo de 1958, Revista de Derecho y Jurisprudencia, t. LV, sec. $1^{\text {a }}$, pp. 71 ss.

Barros Hurtado, José con Rojas, Luis y otro (1955): Corte Suprema, 11 de noviembre de 1955, Revista de Derecho y Jurisprudencia., t. LII, sec. 1a, pp. 362 y ss.

Corte Suprema, 14 de mayo de 1955, Revista de Derecho y Jurisprudencia, t. LII, sec. 1a, pp. 99 y ss.

Corte Suprema, 6 de abril de 1939, Revista de Derecho y Jurisprudencia, t. XXXVII, sec. $1^{\mathrm{a}}$,pp. 1-3. 